\title{
KURUMSAL YÖNETİşIM: Teorik Bir Çözümleme Denemesi
}

\author{
Olcay ÖLÇEN
}




\title{
(C) Copyright 2020
}

Bu kitabın, basım, yayın ve satış hakları Akademisyen Kitabevi A.Ş.'ne aittir. Anılan kuruluşun izni alınmadan kitabın tümü ya da bölümleri mekanik, elektronik, fotokopi, manyetik kağıt ve/veya başka yöntemlerle çoğaltılamaz, basılamaz, dağıtılamaz. Tablo, şekil ve grafikler izin alnmadan, ticari amaçh kullanılamaz. Bu kitap T.C. Kültür Bakanh̆̆̆ bandrolü ile satılmaktadır.

ISBN

978-625-7106-56-6

Kitap Adı

Kurumsal Yönetişim: Teorik Bir Çözümleme Denemesi

\author{
Yazar \\ Olcay ÖLÇEN
}

Yayın Koordinatörü

Yasin Dilmen

Sayfa ve Kapak Tasarımı

Akademisyen Dizgi Ünitesi

Yayıncı Sertifika No

25465

Baskı ve Cilt

Bisac Code

GENEL DAĞITIM

Akademisyen Kitabevi A.Ş.

Halk Sokak 5 / A

Yenişehir / Ankara

Tel: o312 4311633

siparis@akademisyen.com 


\section{TEŞEKKÜR}

Bugünlere kadar beni yetiştiren aileme, beni eleştiren, yerenancak her zaman bir kalp payı bırakan başta Arzum Çelik olmaküzere değerli hocalarıma ve tüm okuyuculara teşekkür ederim. Türkiye Kurumsal Yönetim Derneği’ne ve Sn. Hande Gürtepe’ye ayrıca teşekkür ederim. 



\section{ÖNSÖZ}

Kurumsal yönetişimin teorik bir çözümlenmesinin denendiği bu çalışmada yazar, kurumsal yönetişimin sadece bir etiket olmadığını, arkasında teorilerin, yaklaşımların ve geniş bir külliyatın olduğunu örnekler ile inceleme amacı gütmektedir.

Yazarı bu çalışmayı yapmak konusunda harekete geçiren temel güdü, bugün kurumsal yönetişim adını verdiğimiz kavramdaki boşlukların ancak iktisadî düşüncenin öncülüğünde çözülebileceği düşüncesidir. Yazarı bu görüşe sevk eden, yönetim bilimlerinin ve özellikle finansman biliminin iktisat biliminden bir ebeveyn-çocuk ilişkisinde olduğu gibi etkilenmesidir.

Bugün iktisada yön veren düşünceler, iktisadı bilinen homo economicus'tan koparmaya evrilmektedir. Kurumsal yönetişim de bu uğraşların dolaylı ya da doğrudan bir sonucudur.

Kitabın yararlı olacağı umuduyla...

Olcay Ölçen - Mayıs 2020 
- vi - 


\section{İ̧̧iNDEKILER}

Giriş 1

\section{BÖLÜM Finansal ve İktisadî Teoriler Işs̆ğında, Sürekli Evrim Geçiren Bir Yapı: Kurumsal Yönetişim}

1. Kurumsal Yönetişim Kavramının Kökenleri ..............................................................

1.1. Fayda, Faydacilık ve Fayda Teorileri ...................................................................

1.1.1. Fayda (Utility) Nedir? ..............................................................................

1.1.2. Faydacılık (Utilitaranism) ..........................................................................

1.1.3. Fayda Teorileri .........................................................................................9

1.1.4. Fayda, Faydacılık ve Fayda Teorisi Üzerine Diğer Bilimsel

Çalışmalardan Örnekler ........................................................................................ 10

1.2. Hazcilık ve Hazcı Teoriler .................................................................................14

1.2.1. Hazcıllğın Düşünsel Soy kütüğü ...............................................................14

1.2.2. İktisadî Hazcılık, Hazcı ve Hazcı Davranış ...................................................15

1.2.3. Hazc1 Teoriler........................................................................................

1.2.4. Hazcılık ve Haz Teorileri İle İlgili Diğer Çalışmalar..................................18

1.3. Rasyonalizm ve Sinırlı Rasyonellik ....................................................................19

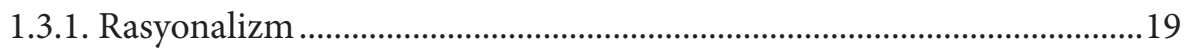

1.3.2. Sinırlı Rasyonalizm ...............................................................................22

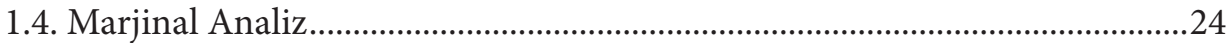

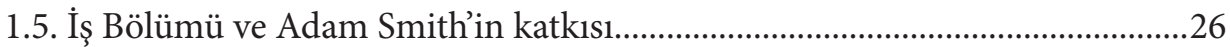

1.6. Mülkiyet Hakları Teorisi, Sözleşmeler Teorisi ve İktisadî Hukuk Yaklaşımı32

1.6.1. Mülkiyet Hakları Teorisi.............................................................................33

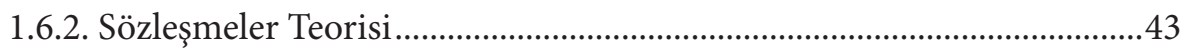

1.6.3. İktisat ile Hukuk Yaklaşımı .........................................................................4

1.7. Mikro, Makro, Kurumsal İktisat ve Kurumlar İle İlgili Çalışmalar................56

1.7.1. Mikro İktisat Teorisi ve Kurumlar İle İlgili Çalışmalar .............................56

1.7.2. Makro İktisat Teori ve Kurumlar İle İlgili Bazı Çalışmalar .....................58

1.7.3. Kurumsal İktisat Yaklaşımları ve Kurumlar ile İlgili Bazı Çalışmalar..68

1.8. Oyun Teorisi ve Kurumlar .74 


\section{BÖLÜM Kurumsal Yönetişim Kavramının Finansman-İşletme ve Yönetim Bilimleri Teorileri Açısından Tarihî Kökenleri}

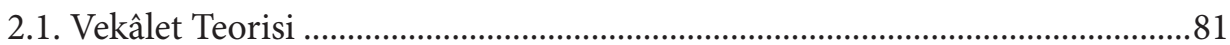

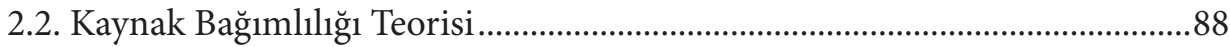

2.3. İşlem Maliyetleri Teorisi (İşlem Maliyetleri Ekonomisi Teorisi) .....................91

2.4. Paydaş ve Hissedar Teorileri ..................................................................................95

2.4.1. "Hissedar teorisi" ve "paydaş teorisi” ile arasındaki farklar...................102

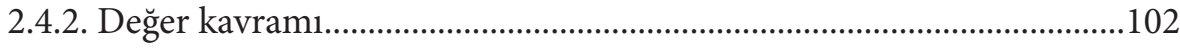

2.4.3. Hissedar değeri ve hissedar teorisi.............................................................103

2.4.4. Paydaş değeri ve paydaş teorisi..................................................................105

2.5. Temsil (Stewardship) Teorisi ........................................................................107

2.6. Kurumsal Sosyal Performans Teorisi.................................................................110

2.7. Bütünleştirici Sosyal Sözleşme Teorisi ...........................................................113

2.8. Kaynak Temelli İşletme Teorisi .........................................................................117

\section{BÖLÜM Kurumsal Yönetişim Kavramının Etik Teorileri Açısından} Kökenleri

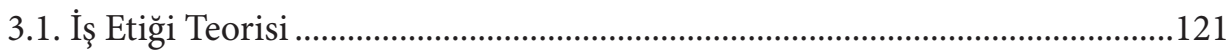

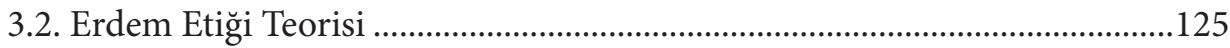

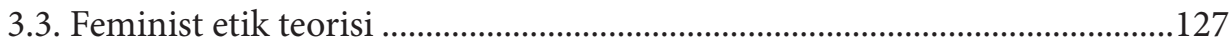

3.4. Söylem Etiği Teorisi ...............................................................................128

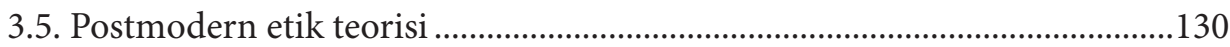

\section{BÖLÜM Kültür Değişkeni}

4.1. Kültür, Örgüt kültürü ve Hofstede ..................................................................133

4.2. Kültür, Örgüt Kültürü, Kurumlar ve Kurumsal Yönetişim..............................137

5.1. Kurumsal yönetişim ile ilgili temel araçlar .....................................................155

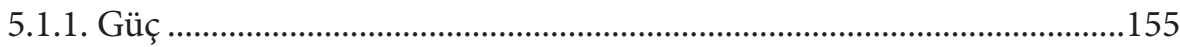

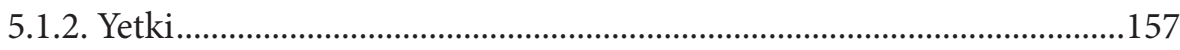

5.1.3. Sorumluluk ve Yetki Devri ....................................................................159

5.1.4. İzleme (Monitoring) ile Değerlendirme (Evaluation) ............................159

5.1.5. Kontrol etme (Controlling) ........................................................................

5.1.5.1. Örgütlerde iç kontrol (internal controlling) ........................................161 
5.1.6. Denetim (Auditing)

5.1.7. Basel ve SOLVENCY düzenlemelerinde sıklıkla bahsedilen bir kavram: Teftiş “(nezaret, supervision)" .................................................................................

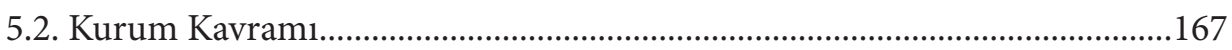

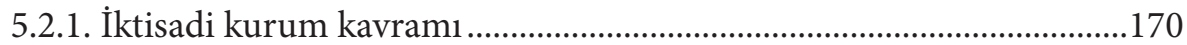

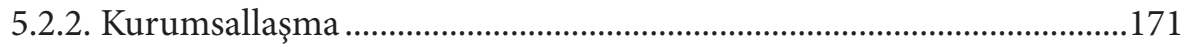

5.2.3. Kurumsal yönetim ile kurumsal yönetişim arasındaki semantik (anlambilimsel) farklar....................................................................................171

5.2.4. Hissedar ve paydaş kavramları ..................................................................172

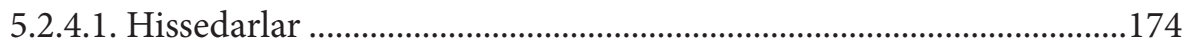

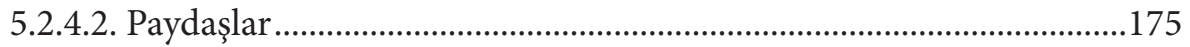

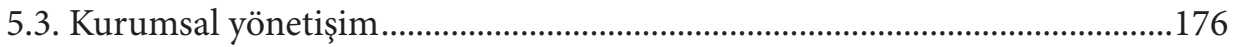

5.3.1. Kurumsal Yönetişimin ilkeleri ..................................................................176

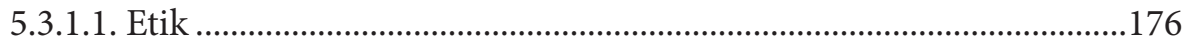

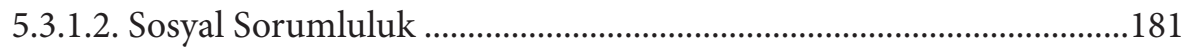

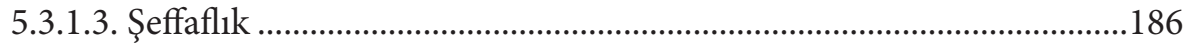

5.3.1.4. Hesap verebilirlik................................................................................. 190

5.3.2. Kurumsal Yönetişim Mekanizmalar1 ..........................................................192

\section{BÖLÜM Girişimcilik, Aile İşletmeleri ve Kurumsal Yönetişim}

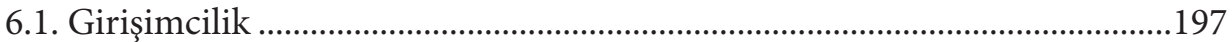

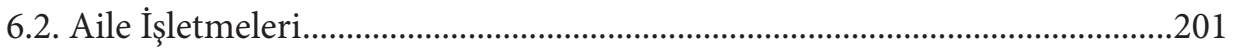

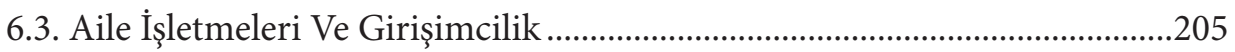

6.4. Aile İşletmeleri, Girişimcilik Ve Kurumsal Yönetişim .....................................205

6.5. Teknoloji, İktisat, Finans ve Yönetim Bilimleri ..................................................210

6.5.1. Finansal Krizler ve Teknoloji İlişkisi........................................................210

\section{BÖLÜM Kurumsal Yönetişime Evrilen Yapı ve Uygulama Örnekleri}

7.1. Finansal ve Muhasebe Sistemlerindeki Krizler ve Sonrasindaki

Düzenlemeler.

7.1.1. Amerika Birleşik Devletleri Örnekleminde Finansal ve Muhasebe Sistemlerindeki Düzenlemeler Tarihçesi 
7.1.2. Muhasebe ve Finans Sisteminin Kalitesi,

Enron Skandalı ve Sarbanes-Oxley ……………………………………….....222

7.1.2.1.Enron skandalının/krizinin bazı finansal sonuçları .............................225

7.1.2.2. Enron skandalının/krizinin kurumsal yönetim/kurumsal yönetişime

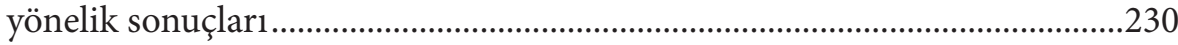

7.1.2.3.Enron sonrası yeni bir yasal düzenleme Sarbanes-Oxley yasas1 .......232

7.2. Bankacılık, Basel Komitesi ve Basel Kriterleri................................................238

7.2.1. Basel Komitesi ve Basel Kriterleri: Uluslararası Bankacılık Sisteminde Kurumsal Yönetişim mi ve/veya Regülasyon mu? ............................................239

7.2.1.1. Basel komitesi çalışmalarına da konu olan bankaların maruz kaldığ riskler

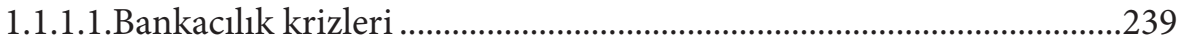

7.2.1.3. Bankacılık krizlerinin doğal sonucu olarak Basel komitesi..............244

7.2.1.4. Bir regülasyon zinciri olarak Basel Kriterleri ......................................245

7.2.1.4.1. Basel 2 Kriterleri..................................................................................251

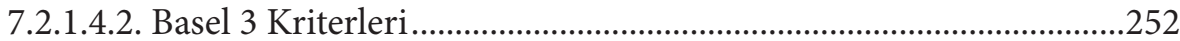

7.2.1.4.3. Basel Komitesi, Basel 1, Basel 2 ve Basel 3’e yönelik eleştiriler......253

7.2.1.5. Bankalarda Kurumsal Yönetim ............................................................257

7.2.1.5.1. Basel ve Bankalarda Kurumsal Yönetim ...........................................257

7.2.1.5.2. Basel 2 ve Piyasa Disiplini ..................................................................257

7.2.1.6. Bankacıllkta kurumsal yönetişim.........................................................259

7.2.1.6.1. Bankacilıkta Etik ...............................................................................259

7.2.1.6.2. Bankacillkta Sosyal Sorumluluk........................................................260

7.2.1.6.3. Bankacıllkta Şeffaflık...........................................................................261

7.2.1.6.4. Bankacıllkta Hesap Verebilirlik ............................................................262

7.2.1.7. Bankalarda kurumsal yönetim/yönetişim üzerine eleştiriler ............263

7.3. Sigortacılıkta Kurumsal Yönetişim ve SOLVENCY Serileri...........................264

7.3.1. Sigortacılık sektöründe riskler ve krizler ..................................................265

7.3.2. Sigortacilıkta "SOLVENCY Serileri" .......................................................268

7.3.2.1. SOLVENCY Serileri tarihçesi ...............................................................268

7.3.2.2. SOLVENCY 1 ve SOLVENCY 2 arasındaki farklar.............................269

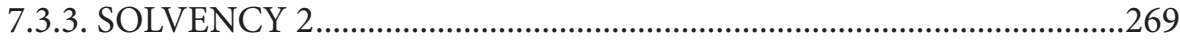


7.3.3.1. SOLVENCY 2 Projesinin amaçları......................................................2270

7.3.3.2. SOLVENCY 2 Projesinin faydaları ..................................................2.270

7.3.3.3. SOLVENCY 2 PROJESİ

7.3.3.4.7. SOLVENCY 2 ile ilgili eleştiriler

7.3.3.5.7. Sigortacılıkta Kurumsal Yönetişim

Kaynakça .........................................................................................395 


\section{KAYNAKÇA}

1. Abdel-Khalik, A. R. (2002). Reforming corporate governance post Enron: Shareholders' Board of Trustees and the auditor. Journal of Accounting and Public Policy, 21(2), 97-103.

2. Abdullah, H., \& Valentine, B. (2009). Fundamental and ethics theories of corporate governance. Middle Eastern Finance and Economics, 4(4), 88-96.

3. Abe, N., \& Shimizutani, S. (2007). Employment policy and corporate governance-An empirical comparison of the stakeholder and the profit-maximization model. Journal of Comparative Economics, 35(2), 346-368.

4. Abrahamson, E., \& Park, C. (1994). Concealment of negative organizational outcomes: An agency theory perspective. Academy of management journal, 37(5), 1302-1334.

5. Acar, O. (2007). Avrupa Birliği Solvency II Projesi. Türkiye Sigorta ve Reasürans Şirketleri Birliği (TSRSB).

6. Acedo, F. J., Barroso, C., \& Galan, J. L. (2006). The resource区based theory: dissemination and main trends. Strategic management journal, 27(7), 621-636.

7. Acharya, V. V., \& Volpin, P. F. (2010). Corporate governance externalities. Review of Finance, 14(1), 1-33.

8. Ackerman, B. A. (1986). Law, economics, and the problem of legal culture. Duke LJ, 929.

9. Adams, M. B. (1994). Agency theory and the internal audit. Managerial auditing journal.

10. Adams, R. M. (1976). Motive utilitarianism. The journal of Philosophy, 73(14), 467-481.

11. Aggarwal, R. (2014). Animal spirits in financial economics: A review of deviations from economic rationality. International Review of Financial Analysis, 32, 179-187.

12. Agrawal, A., \& Ostrom, E. (2001). Collective action, property rights, and decentralization in resource use in India and Nepal. Politics \& Society, 29(4), 485-514.

13. Aguilera, R. V., \& Jackson, G. (2003). The cross-national diversity of corporate governance: Dimensions and determinants. Academy of management Review, 28(3), 447-465.

14. Aguilera, R. V., \& Jackson, G. (2010). Comparative and international corporate governance. The academy of management annals, 4(1), 485-556.

15. Ağca, A., \& Aktaş, R. (2007). First time application of IFRS and its impact on financial ratios: a study on Turkish listed firms. Problems and Perspectives in Management, 5(2), 99-112.

16. Ahrens, T., Filatotchev, I., \& Thomsen, S. (2011). The research frontier in corporate governance. Journal of Management \& Governance, 15(3), 311-325.

17. Akhigbe, A., \& Martin, A. D. (2006). Valuation impact of Sarbanes-Oxley: Evidence from disclosure and governance within the financial services industry. Journal of Banking \& Finance, 30(3), 989-1006.

18. Albrecht, W., Conan C. Albrecht, and Chad O. Albrecht. "Fraud and corporate executives: Agency, stewardship and broken trust." (2004): 109-130.

19. Alexander, E. R. (2000). Rationality revisited: Planning paradigms in a post-postmodernist perspective. Journal of planning education and research, 19(3), 242-256.

20. Al-Hamdi, M. T. (2006, November). Ibn Khaldun: The father of the division of labor. In international Conference on Ibn Khaldun, Madrid (Vol. 23).

21. Alston, L. J., \& Mueller, B. (2008). Property rights and the state. In Handbook of new institutional economics (pp. 573-590). Springer, Berlin, Heidelberg.

22. Alvarez, S. A., \& Busenitz, L. W. (2001). The entrepreneurship of resource-based theory. Journal of management, 27(6), 755-775.

23. Andersen, O., \& Kheam, L. S. (1998). Resource-based theory and international growth strategies: an exploratory study. International Business Review, 7(2), 163-184.

24. Anderson, E., \& Gatignon, H. (1986). Modes of foreign entry: A transaction cost analysis and propositions. Journal of international business studies, 17(3), 1-26.

25. Anderson, T. L., \& Hill, P. J. (1975). The evolution of property rights: a study of the American West. The Journal of Law and Economics, 18(1), 163-179. 
26. Andolfatto, D. (2002). A theory of inalienable property rights. Journal of Political Economy, $110(2), 382-393$.

27. Andries, K., Gallemore, J., \& Jacob, M. (2017). The effect of corporate taxation on bank transparency: Evidence from loan loss provisions. Journal of Accounting and Economics, 63(2-3), 307-328.

28. Argenziano, R., \& Gilboa, I. (2019). Perception-theoretic foundations of weighted utilitarianism. The Economic Journal, 129(620), 1511-1528.

29. Argyres, N. S., \& Liebeskind, J. P. (1999). Contractual commitments, bargaining power, and governance inseparability: Incorporating history into transaction cost theory. Academy of management review, 24(1), 49-63.

30. Arjoon, S. (2000). Virtue theory as a dynamic theory of business. Journal of Business Ethics, 28(2), 159-178.

31. Arnold, U. (2000). New dimensions of outsourcing: a combination of transaction cost economics and the core competencies concept. European journal of purchasing \& supply management, 6(1), 23-29.

32. Aronoff, C. E. (1998). Megatrends in family business. Family business review, 11(3), 181-186.

33. Arora, A., \& Merges, R. P. (2004). Specialized supply firms, property rights and firm boundaries. Industrial and Corporate Change, 13(3), 451-475.

34. Arrow, K. J. (1986). Rationality of self and others in an economic system. Journal of Business, S385-S399.

35. Arthur, W. B. (1994). Inductive reasoning and bounded rationality. The American economic review, 84(2), 406-411.

36. Arthur, W. B. (1994). Inductive reasoning and bounded rationality. The American economic review, 84(2), 406-411.

37. Arthurs, J. D., \& Busenitz, L. W. (2003). The boundaries and limitations of agency theory and stewardship theory in the venture capitalist/entrepreneur relationship. Entrepreneurship Theory and Practice, 28(2), 145-162.

38. Arun, T. G., \& Turner, J. D. (2004). Corporate governance of banks in developing economies: Concepts and issues. Corporate Governance: An International Review, 12(3), 371-377.

39. Asher, C. C., Mahoney, J. M., \& Mahoney, J. T. (2005). Towards a property rights foundation for a stakeholder theory of the firm. Journal of Management \& Governance, 9(1), 5-32.

40. Audi, R. (2012). Virtue ethics as a resource in business. Business Ethics Quarterly, 22(2), 273-291.

41. Audretsch, D. B., Lehmann, E. E., \& Seitz, N. (2019). Amenities, subcultures, and entrepreneurship. Small Business Economics, 1-21.

42. Azis, N., \& Basri, H. (2019). Intellectual Capital and Financial Performance: The Role of Good Corporate Governance (Study on Islamic Banking in Indonesia). KnE Social Sciences, 1-9.

43. Backman, C. A., Verbeke, A., \& Schulz, R. A. (2017). The drivers of corporate climate change strategies and public policy: a new resource-based view perspective. Business \& Society, 56(4), 545-575.

44. Bae, S. C., Chang, K., \& Kang, E. (2012). Culture, corporate governance, and dividend policy: international evidence. Journal of Financial Research, 35(2), 289-316.

45. Bahli, B., \& Rivard, S. (2003). The information technology outsourcing risk: a transaction cost and agency theory凶based perspective. Journal of Information Technology, 18(3), 211-221.

46. Bai, C. E., Liu, Q., Lu, J., Song, F. M., \& Zhang, J. (2004). Corporate governance and market valuation in China. Journal of comparative economics, 32(4), 599-616.

47. Baker, G., \& Hubbard, T. N. (2001). Empirical strategies in contract economics: Information and the boundary of the firm. American Economic Review, 91(2), 189-194.

48. Balin, B. J. (2008). Basel I, Basel II, and emerging markets: A nontechnical analysis. Available at SSRN 1477712.

49. Baluch, F., Mutenga, S., \& Parsons, C. (2011). Insurance, systemic risk and the financial crisis. The Geneva Papers on Risk and Insurance-Issues and Practice, 36(1), 126-163. 
50. Barakat, A., \& Hussainey, K. (2013). Bank governance, regulation, supervision, and risk reporting: Evidence from operational risk disclosures in European banks. International Review of Financial Analysis, 30, 254-273.

51. Barney, J. B. (2001). Is the resource-based "view" a useful perspective for strategic management research? Yes. Academy of management review, 26(1), 41-56.

52. Barney, J. B., Ketchen Jr, D. J., \& Wright, M. (2011). The future of resource-based theory: revitalization or decline?. Journal of management, 37(5), 1299-1315.

53. Barr, M. S., \& Miller, G. P. (2006). Global administrative law: the view from Basel. European Journal of International Law, 17(1), 15-46.

54. Barratt, M., \& Oke, A. (2007). Antecedents of supply chain visibility in retail supply chains: a resource-based theory perspective. Journal of operations management, 25(6), 1217-1233.

55. Barrotta, P. (2008). Why economists should be unhappy with the economics of happiness. Economics \& Philosophy, 24(2), 145-165.

56. Barth, J. R., Caprio, G., \& Levine, R. (2004). Bank supervision and regulation: What works best?.

57. Bashir, U., Yu, Y., Hussain, M., Wang, X., \& Ali, A. (2017). Do banking system transparency and competition affect nonperforming loans in the Chinese banking sector?. Applied Economics Letters, 24(21), 1519-1525.

58. Baskerville, R. F. (2003). Hofstede never studied culture. Accounting, organizations and society, 28(1), 1-14.

59. Bathala, C. T., \& Rao, R. P. (1995). The determinants of board composition: An agency theory perspective. Managerial and decision economics, 16(1), 59-69.

60. Baumgardner, J. R. (1988). The division of labor, local markets, and worker organization. Journal of Political Economy, 96(3), 509-527.

61. Baumol, W. J. (1968). Entrepreneurship in economic theory. The American economic review, 58(2), 64-71.

62. Baumol, W. J. (1996). Entrepreneurship: Productive, unproductive, and destructive. Journal of business venturing, 11(1), 3-22.

63. Baumol, W. J., \& Bradford, D. F. (1970). Optimal departures from marginal cost pricing. The American Economic Review, 60(3), 265-283.

64. Beccerra, M., \& Gupta, A. K. (1999). Trust within the organization: Integrating the trust literature with agency theory and transaction costs economics. Public Administration Quarterly, 177-203.

65. Bell, F. W., \& Murphy, N. B. (1968). Economies of scale and division of labor in commercial banking. Southern Economic Journal, 131-139.

66. Benston, G. J., \& Hartgraves, A. L. (2002). Enron: What happened and what we can learn from it. Journal of Accounting and Public Policy, 21(2), 105-127.

67. Berger, A. N., \& Di Patti, E. B. (2006). Capital structure and firm performance: A new approach to testing agency theory and an application to the banking industry. Journal of Banking \& Finance, 30(4), 1065-1102.

68. Bergh, D. D. (1995). Size and relatedness of units sold: An agency theory and resource区based perspective. Strategic Management Journal, 16(3), 221-239.

69. Berliant, M., \& McMillen, D. P. (2006). Hedonism vs. nihilism: No arbitrage and tests of urban economic models. Regional Science and Urban Economics, 36(1), 118-131.

70. Berry®Stölzle, T. R., Nini, G. P., \& Wende, S. (2014). External financing in the life insurance industry: evidence from the financial crisis. Journal of Risk and Insurance, 81(3), 529-562.

71. Beschorner, T. (2006). Ethical theory and business practices: The case of discourse ethics. Journal of Business Ethics, 66(1), 127-139.

72. Besley, T. (1995). Property rights and investment incentives: Theory and evidence from Ghana. Journal of political Economy, 103(5), 903-937.

73. Bicchieri, C. (1987). Rationality and predictability in economics. The British journal for the philosophy of science, 38(4), 501-513. 
74. Bidabad, B. (2019). Equilibrium in ethic economics. International Journal of Islamic Business \& Management, 3(2), 16-23.

75. Billings, M., \& Capie, F. (2009, March). Transparency and financial reporting in mid-20th century British banking. In Accounting Forum (Vol. 33, No. 1, pp. 38-53). Taylor \& Francis.

76. Billio, M., Getmansky, M., Lo, A. W., \& Pelizzon, L. (2012). Econometric measures of connectedness and systemic risk in the finance and insurance sectors. Journal of financial economics, 104(3), 535-559.

77. Bils, M. (1987). The cyclical behavior of marginal cost and price. The American Economic Review, 838-855.

78. Blackorby, C., Bossert, W., Donaldson, D., Arrow, K., Sen, A., \& Suzumura, K. (1999). Utilitarianism and the theory of justice. School of Economics, University of Nottingham.

79. Blackorby, C., Bossert, W., Donaldson, D., Arrow, K., Sen, A., \& Suzumura, K. (1999). Utilitarianism and the theory of justice. School of Economics, University of Nottingham.

80. Blaug, R. (2000). Citizenship and political judgment: between discourse ethics and phronesis. Res Publica, 6(2), 179-198.

81. Blundell-Wignall, A., \& Atkinson, P. (2010). Thinking beyond basel iii. OECD Journal: Financial Market Trends, 2010(1), 9-33.

82. Boatright, J. R. (1996). Business ethics and the theory of the firm. Am. Bus. LJ, 34, 217.

83. Bonsón囚Ponte, E., Escobar囚Rodríguez, T., \& Flores $\bigotimes$ Muñoz, F. (2006). Online transparency of the banking sector. Online information review.

84. Borgerson, J. L. (2007). On the harmony of feminist ethics and business ethics.

85. Borjas, G. J., Frech III, H. E., \& Ginsburg, P. B. (1983). Property rights and wages: The case of nursing homes. Journal of Human Resources, 231-246.

86. Borsky, S., \& Raschky, P. A. (2009). The Hedonics of Hedonism-Estimating the Value of Risk $\mathbb{X}$ Taking Activities. Kyklos, 62(2), 210-225.

87. Botzen, W. J. W., Van den Bergh, J. C. J. M., \& Bouwer, L. M. (2010). Climate change and increased risk for the insurance sector: a global perspective and an assessment for the Netherlands. Natural hazards, 52(3), 577-598.

88. Boubakri, N., Cosset, J. C., \& Guedhami, O. (2005). Liberalization, corporate governance and the performance of privatized firms in developing countries. Journal of Corporate Finance, 11(5), 767-790.

89. Boyd, B. (1990). Corporate linkages and organizational environment: A test of the resource dependence model. Strategic management journal, 11(6), 419-430.

90. Brabeck, M. M., \& Ting, K. (2000). Feminist ethics: Lenses for examining ethical psychological practice.

91. Braendle, U. C., Gasser, T., \& Noll, J. (2005). Corporate governance in China-is economic growth potential hindered by guanxi?. Business and Society Review, 110(4), 389-405.

92. Brandt, R. B. (1972). Utilitarianism and the Rules of War. Philosophy \& Public Affairs, 145-165.

93. Branson, D. M. (2003). Enron-When All Systems Fail: Creative Destruction or Roadmap to Corporate Governance Reform. Vill. L. Rev., 48, 989.

94. Bratton, W. W. (2001). Enron and the dark side of shareholder value. Tul. L. Rev., 76, 1275.

95. Bravo, R., Buil, I., de Chernatony, L., \& Martínez, E. (2017). Brand Identity Management and Corporate Social Responsibility: an analysis from employees' perspective in the banking sector. Journal of Business Economics and Management, 18(2), 241-257.

96. Brennan, N. M., Solomon, J., Uddin, S., \& Choudhury, J. (2008). Rationality, traditionalism and the state of corporate governance mechanisms. Accounting, Auditing \& Accountability Journal.

97. Brennan, S. (1999). Recent work in feminist ethics. Ethics, 109(4), 858-893.

98. Brey, P. (2012). Well-being in philosophy, psychology, and economics. In The good life in a technological age (pp. 33-52). Routledge.

99. Brink, D. O. (1992). Mill's deliberative utilitarianism. Philosophy \& Public Affairs, 67-103. 
100. Brock, D. W. (1973). Recent work in utilitarianism. American Philosophical Quarterly, 10(4), 241-276.

101. Brown, D. G. (1973). What is Mill's principle of utility?. Canadian Journal of Philosophy, 3(1), $1-12$.

102. Bruni, L. (2010). The happiness of sociality. Economics and eudaimonia: A necessary encounter. Rationality and Society, 22(4), 383-406.

103. Buck, T., \& Shahrim, A. (2005). The translation of corporate governance changes across national cultures: The case of Germany. Journal of International Business Studies, 36(1), 42-61.

104. Buckley, P. J., Munjal, S., Enderwick, P., \& Forsans, N. (2017). The role of country alliances in reducing the transaction costs of internationalisation: evidence from Indian multinational enterprises. Cambridge Journal of Economics, 41(3), 807-828.

105. Burton, B. K., \& Dunn, C. P. (1996). Feminist ethics as moral grounding for stakeholder theory. Business ethics quarterly, 133-147.

106. Busse, C., Regelmann, A., Chithambaram, H., \& Wagner, S. M. (2017). Managerial perceptions of energy in logistics. International Journal of Physical Distribution \& Logistics Management.

107. Butler, J., Morrice, D. J., \& Mullarkey, P. W. (2001). A multiple attribute utility theory approach to ranking and selection. Management Science, 47(6), 800-816.

108. Butt, M. (2007). Insurance, finance, Solvency II and financial market interaction. The Geneva Papers on Risk and Insurance-Issues and Practice, 32(1), 42-45.

109. Byrd, E. T. (2007). Stakeholders in sustainable tourism development and their roles: applying stakeholder theory to sustainable tourism development. Tourism review.

110. Caballero, R., \& Hammour, M. (2001). Institutions, restructuring and macroeconomic performance. In Advances in Macroeconomic Theory (pp. 171-193). Palgrave Macmillan, London.

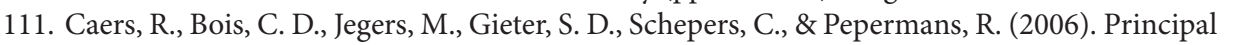
agent relationships on the stewardship囚agency axis. Nonprofit Management and Leadership, $17(1), 25-47$.

112. Cafaro, P. (2001). Thoreau, Leopold, and Carson: Toward an environmental virtue ethics. Environmental ethics, 23(1), 3-17.

113. Cahan, S. F., \& Zhang, W. (2006). After Enron: Auditor conservatism and ex-Andersen clients. The Accounting Review, 81(1), 49-82.

114. Caldeira, M. M., \& Ward, J. M. (2003). Using resource-based theory to interpret the successful adoption and use of information systems and technology in manufacturing small and medium-sized enterprises. European Journal of information systems, 12(2), 127-141.

115. Campbell, J. M., \& Park, J. (2017). Extending the resource-based view: Effects of strategic orientation toward community on small business performance. Journal of Retailing and Consumer Services, 34, 302-308.

116. Candan, H., \& Özün, A. (2014). Bankalarda Risk Yönetimi ve Basel II,(3. Basım). İstanbul: Türkiye İş Bankası Kültür Yayınları.

117. Cannata, F., \& Quagliariello, M. (2009). The role of Basel II in the subprime financial crisis: guilty or not guilty?. CAREFIN Research Paper, (3/09).

118. Cantor, R. (2001). Moody's investors service response to the consultative paper issued by the Basel Committee on Bank Supervision "A new capital adequacy framework". Journal of Banking \& Finance, 25(1), 171-185.

119. Caplin, A., \& Leahy, J. (2001). Psychological expected utility theory and anticipatory feelings. The Quarterly Journal of Economics, 116(1), 55-79.

120. Caprio, G., \& Honohan, P. (1999). Restoring banking stability: beyond supervised capital requirements. Journal of Economic Perspectives, 13(4), 43-64.

121. Carland, J. W., Hoy, F., Boulton, W. R., \& Carland, J. A. C. (2007). Differentiating entrepreneurs from small business owners: A conceptualization. In Entrepreneurship (pp. 73-81). Springer, Berlin, Heidelberg.

122. Carson, T. L. (2003). Self-interest and business ethics: Some lessons of the recent corporate scandals. Journal of Business Ethics, 43(4), 389-394. 
123. Carson, T. L. (2003). Self-interest and business ethics: Some lessons of the recent corporate scandals. Journal of Business Ethics, 43(4), 389-394.

124. Casciaro, T., \& Piskorski, M. J. (2005). Power imbalance, mutual dependence, and constraint absorption: A closer look at resource dependence theory. Administrative science quarterly, 50(2), 167-199.

125. Catarineu-Rabell, E., Jackson, P., \& Tsomocos, D. P. (2005). Procyclicality and the new Basel Accord-banks' choice of loan rating system. Economic Theory, 26(3), 537-557.

126. Cava, A., \& Mayer, D. (2007). Integrative social contract theory and urban prosperity initiatives. Journal of Business Ethics, 72(3), 263-278.

127. Cerin, P., \& Karlson, L. (2002). Business incentives for sustainability: a property rights approach. Ecological economics, 40(1), 13-22.

128. Chan, A., \& Garrick, J. (2002). Organization theory in turbulent times: The traces of Foucault's ethics. Organization, 9(4), 683-701.

129. Chandra, R. (2004). Adam Smith, Allyn Young, and the division of labor. Journal of Economic Issues, 38(3), 787-805.

130. Charreaux, G. J. (2004). Corporate governance theories: From micro theories to national systems theories. Université De Bourgogne Fargo Working Paper, (1040101).

131. Chen, J. V., Su, B. C., \& Hiele, T. M. (2017). The impact of IT-coordination costs on firm size and productivity: transaction cost perspective. International Journal of Electronic Commerce, 21(1), 99-127.

132. Chiles, T. H., \& McMackin, J. F. (1996). Integrating variable risk preferences, trust, and transaction cost economics. Academy of management review, 21(1), 73-99.

133. Chomvilailuk, R., \& Butcher, K. (2010). Enhancing brand preference through corporate social responsibility initiatives in the Thai banking sector. Asia Pacific Journal of Marketing and Logistics.

134. Chowdhury, F., Audretsch, D. B., \& Belitski, M. (2019). Institutions and entrepreneurship quality. Entrepreneurship Theory and Practice, 43(1), 51-81.

135. Chrisman, J. J., Chua, J. H., \& Steier, L. P. (2003). An introduction to theories of family business.

136. Christen, M., Iyer, G., \& Soberman, D. (2006). Job satisfaction, job performance, and effort: A reexamination using agency theory. Journal of marketing, 70(1), 137-150.

137. Chua, J. H., Chrisman, J. J., \& Sharma, P. (1999). Defining the family business by behavior. Entrepreneurship theory and practice, 23(4), 19-39.

138. CIUMAŞ, C., Oniga, A., \& Coca, R. A. (2014). Facing The Implementation Challenges Of The Solvency Ii Directive. Revista Economică, 66(2).

139. Claessens, S. (2006). Corporate governance and development. The World bank research observer, 21(1), 91-122.

140. Claessens, S., \& Fan, J. P. (2002). Corporate governance in Asia: A survey. International Review of finance, 3(2), 71-103.

141. Clarke, T. (2005). Accounting for Enron: shareholder value and stakeholder interests. Corporate Governance: An International Review, 13(5), 598-612.

142. Clarkson, M. E. (1995). A stakeholder framework for analyzing and evaluating corporate social performance. Academy of management review, 20(1), 92-117.

143. Clement, M. B., Rees, L., \& Swanson, E. P. (2003). The influence of culture and corporate governance on the characteristics that distinguish superior analysts. Journal of Accounting, Auditing \& Finance, 18(4), 593-618.

144. Coase, R. H. (1946). The marginal cost controversy. Economica, 13(51), 169-182.

145. Coase, R. H. (1960). The problem of social cost. In Classic papers in natural resource economics (pp. 87-137). Palgrave Macmillan, London.

146. Coates, I. V., \& John, C. (2007). The goals and promise of the Sarbanes-Oxley Act. Journal of economic perspectives, 21(1), 91-116.

147. Cockburn, T. (2005). Children and the feminist ethic of care. Childhood, 12(1), 71-89. 
148. Coff, R. W. (1997). Human assets and management dilemmas: Coping with hazards on the road to resource-based theory. Academy of management review, 22(2), 374-402.

149. Coffee Jr, J. C. (2003). What caused enron-a capsule social and economic history of the 1990s. Cornell L. Rev., 89, 269.

150. Cohan, J. A. (2002). “I didn’t know" and" I was only doing my job”: Has corporate governance careened out of control? A case study of Enron's information myopia. Journal of Business Ethics, 40(3), 275-299.

151. Combs, J. G., \& Ketchen Jr, D. J. (1999). Can capital scarcity help agency theory explain franchising? Revisiting the capital scarcity hypothesis. Academy of Management Journal, 42(2), 196-207.

152. Commons, J. R. (1925). Law and economics. The Yale Law Journal, 34(4), 371-382.

153. Conlisk, J. (1996). Why bounded rationality?. Journal of economic literature, 34(2), 669-700.,

154. Conlisk, J. (1996). Why bounded rationality?. Journal of economic literature, 34(2), 669-700.,

155. Conner, K. R. (1991). A historical comparison of resource-based theory and five schools of thought within industrial organization economics: do we have a new theory of the firm?. Journal of management, 17(1), 121-154.

156. Conner, K. R., \& Prahalad, C. K. (1996). A resource-based theory of the firm: Knowledge versus opportunism. Organization science, 7(5), 477-501.

157. Conybeare, J. A. (1980). International organization and the theory of property rights. International Organization, 34(3), 307-334.

158. Conyon, M., Judge, W. Q., \& Useem, M. (2011). Corporate governance and the 2008-09 financial crisis. Corporate Governance: An International Review, 19(5), 399-404.

159. Coupet, J., \& McWilliams, A. (2017). Integrating organizational economics and resource dependence theory to explain the persistence of quasi markets. Administrative Sciences, 7(3), 29.

160. Cowton, C. J. (2002). Integrity, responsibility and affinity: three aspects of ethics in banking. Business Ethics: A European Review, 11(4), 393-400.

161. Cragg, W. (2002). Business ethics and stakeholder theory. Business Ethics Quarterly, 12(2), 113-142.

162. Crain, W. M., \& Zardkoohi, A. (1978). A test of the property-rights theory of the firm: water utilities in the United States. The Journal of Law and Economics, 21(2), 395-408.

163. Crane, A., \& Ruebottom, T. (2011). Stakeholder theory and social identity: Rethinking stakeholder identification. Journal of business ethics, 102(1), 77-87.

164. Crawford, S. E., \& Ostrom, E. (1995). A grammar of institutions. American political science review, 89(3), 582-600.

165. Creyer, E. H. (1997). The influence of firm behavior on purchase intention: do consumers really care about business ethics?. Journal of consumer Marketing.

166. Crisp, R. (1992). Utilitarianism and the Life of Virtue. The Philosophical Quarterly (1950-), 42(167), 139-160.

167. Crocker, K. J., \& Masten, S. E. (1996). Regulation and administered contracts revisited: Lessons from transaction-cost economics for public utility regulation. Journal of Regulatory Economics, 9(1), 5-39.

168. Cropsey, J. (1955). What is welfare economics?. Ethics, 65(2), 116-125.

169. Cuervo, A. (2002). Corporate governance mechanisms: A plea for less code of good governance and more market control. Corporate Governance: An International Review, 10(2), 84-93.

170. Cullity, G. (1999). Virtue ethics, theory, and warrant. Ethical Theory and Moral Practice, 2(3), 277-294.

171. Cummins, J. D., \& Weiss, M. A. (2014). Systemic risk and the US insurance sector. Journal of Risk and Insurance, 81(3), 489-528.

172. Çankaya, F. (2007).Uluslararası Muhasebe Uyumunun Ölçülmesine Yönelik Bir Uygulama : Rusya, Çin ve Türkiye Karşılaştırması. ZKÜ Sosyal Bilimler Dergisi, Cilt 3, Sayı 6, 2007, ss. 127-148. 
173. Çoban, N. (2010). Sigortacilık Sektöründe Solvency II Yönetişim Sistemi. Ekonomi Bilimleri Dergisi, 2(2).

174. Daniel, S. J., Cieslewicz, J. K., \& Pourjalali, H. (2012). The impact of national economic culture and country-level institutional environment on corporate governance practices. Management International Review, 52(3), 365-394.

175. Darlap, P., \& Mayr, B. (2006). Group aspects of regulatory reform in the insurance sector. The Geneva Papers on Risk and Insurance-Issues and Practice, 31(1), 96-123.

176. Das, D. K. (2001). Corporate governance and restructuring: A post-crisis Asian perspective. The Asia Pacific Journal of Economics \& Business, 5(1), 4.

177. Das, T. K., \& Teng, B. S. (2000). A resource-based theory of strategic alliances. Journal of management, 26(1), 31-61.

178. David, R. J., \& Han, S. K. (2004). A systematic assessment of the empirical support for transaction cost economics. Strategic management journal, 25(1), 39-58.

179. Davidson III, W. N., Jiraporn, P., Kim, Y. S., \& Nemec, C. (2004). Earnings management following duality-creating successions: Ethnostatistics, impression management, and agency theory. Academy of management journal, 47(2), 267-275.

180. Davis, G. F., \& Cobb, J. A. (2010). Resource dependence theory: Past and future. In Stanford's organization theory renaissance, 1970-2000. Emerald Group Publishing Limited.

181. Davis, J. H., Schoorman, F. D., \& Donaldson, L. (1997). Toward a stewardship theory of management. Academy of Management review, 22(1), 20-47.

182. Davis, J., Frankforter, S., Vollrath, D., \& Hill, V. (2007). An empirical test of stewardship theory. Journal of Business \& Leadership: Research, Practice, and Teaching (2005-2012), 3(1), 40-50.

183. Davis, P. J., \& Simpson, E. (2017). Resource-based theory, competition and staff differentiation in Africa: Leveraging employees as a source of sustained competitive advantage. American journal of management, 17(1).

184. De Andres, P., \& Vallelado, E. (2008). Corporate governance in banking: The role of the board of directors. Journal of banking \& finance, 32(12), 2570-2580.

185. De Bakker, F. G., Groenewegen, P., \& Den Hond, F. (2005). A bibliometric analysis of 30 years of research and theory on corporate social responsibility and corporate social performance. Business \& society, 44(3), 283-317.

186. De George, R. T. (1987). The status of business ethics: past and future. Journal of Business ethics, 6(3), 201-211.

187. De Goede, M. (2004). Repoliticizing financial risk. Economy and society, 33(2), 197-217.

188. De Gooyert, V., Rouwette, E., Van Kranenburg, H., \& Freeman, E. (2017). Reviewing the role of stakeholders in operational research: A stakeholder theory perspective. European Journal of Operational Research, 262(2), 402-410.

189. De Liso, N., Filatrella, G., \& Weaver, N. (2001). On endogenous growth and increasing returns: modeling learning-by-doing and the division of labor. Journal of Economic Behavior \& Organization, 46(1), 39-55.

190. De Meza, D., \& Lockwood, B. (1998). Does asset ownership always motivate managers? Outside options and the property rights theory of the firm. The Quarterly Journal of Economics, 113(2), 361-386.

191. De Nicolò, G., Laeven, L., \& Ueda, K. (2008). Corporate governance quality: Trends and real effects. Journal of Financial Intermediation, 17(2), 198-228.

192. Delimatsis, P. (2012). Financial innovation and prudential regulation: The new Basel III rules. J. World Trade, 46, 1309.

193. Dell'Atti, S., Trotta, A., Iannuzzi, A. P., \& Demaria, F. (2017). Corporate social responsibility engagement as a determinant of bank reputation: An empirical analysis. Corporate Social Responsibility and Environmental Management, 24(6), 589-605.

194. Demsetz, H. (1974). Toward a theory of property rights. In Classic papers in natural resource economics (pp. 163-177). Palgrave Macmillan, London. 
195. Denis, D. K., \& McConnell, J. J. (2003). International corporate governance. Journal of financial and quantitative analysis, 38(1), 1-36.

196. Dequech, D. (2006). The new institutional economics and the theory of behaviour under uncertainty. Journal of Economic Behavior \& Organization, 59(1), 109-131.

197. Derry, R., \& Green, R. M. (1989). Ethical theory in business ethics: A critical assessment. Journal of Business Ethics, 8(7), 521-533.

198. Dewing, I. P., \& Russell, P. O. (2004). Accounting, auditing and corporate governance of European listed countries: EU policy developments before and after Enron. JCMS: Journal of Common Market Studies, 42(2), 289-319.

199. Dhami, S., \& Al-Nowaihi, A. (2007). Why do people pay taxes? Prospect theory versus expected utility theory. Journal of Economic Behavior \& Organization, 64(1), 171-192.

200. Dhami, S., \& Al-Nowaihi, A. (2007). Why do people pay taxes? Prospect theory versus expected utility theory. Journal of Economic Behavior \& Organization, 64(1), 171-192.

201. Dharwadkar, B., George, G., \& Brandes, P. (2000). Privatization in emerging economies: An agency theory perspective. Academy of management review, 25(3), 650-669.

202. Dhillon, A., \& Mertens, J. F. (1999). Relative utilitarianism. Econometrica, 67(3), 471-498.

203. Dicke, L. A. (2002). Ensuring accountability in human services contracting: Can stewardship theory fill the bill?. The American Review of Public Administration, 32(4), 455-470.

204. Dicke, L. A., \& Ott, J. S. (2002). A test: can stewardship theory serve as a second conceptual foundation for accountability methods in contracted human services?. International Journal of Public Administration, 25(4), 463-487.

205. Dietz, M. G. (2003). Current controversies in feminist theory. Annual review of political science, 6(1), 399-431.,

206. Dionne, G. (2013). Risk management: History, definition, and critique. Risk Management and Insurance Review, 16(2), 147-166.

207. Dittmar, A., Mahrt-Smith, J., \& Servaes, H. (2003). International corporate governance and corporate cash holdings. Journal of Financial and Quantitative analysis, 38(1), 111-133.

208. Dobson, J. (2004). Applying virtue ethics to business: The agent-based approach. EJBOElectronic Journal of Business Ethics and Organization Studies.

209. Doff, R. (2008). A critical analysis of the Solvency II proposals. The Geneva Papers on Risk and Insurance-Issues and Practice, 33(2), 193-206.

210. Doh, J., Husted, B. W., Matten, D., \& Santoro, M. (2010). Ahoy there! Toward greater congruence and synergy between international business and business ethics theory and research. Business Ethics Quarterly, 20(3), 481-502.

211. Donadelli, M., \& Persha, L. (2014). Understanding emerging market equity risk premia: Industries, governance and macroeconomic policy uncertainty. Research in International Business and Finance, 30, 284-309.

212. Donaldson, L., \& Davis, J. H. (1991). Stewardship theory or agency theory: CEO governance and shareholder returns. Australian Journal of management, 16(1), 49-64.

213. Donaldson, T., \& Dunfee, T. W. (1994). Toward a unified conception of business ethics: Integrative social contracts theory. Academy of management review, 19(2), 252-284.

214. Donaldson, T., \& Dunfee, T. W. (2002). Ties that bind in business ethics: Social contracts and why they matter. Journal of Banking \& Finance, 26(9), 1853-1865.

215. Douglas, M. (2000). Integrative social contracts theory: Hype over hypernorms. Journal of Business Ethics, 26(2), 101-110.

216. Drees, J. M., \& Heugens, P. P. (2013). Synthesizing and extending resource dependence theory: A meta-analysis. Journal of Management, 39(6), 1666-1698.

217. Drew, S. A., Kelley, P. C., \& Kendrick, T. (2006). CLASS: Five elements of corporate governance to manage strategic risk. Business horizons, 49(2), 127-138.

218. Duhs, L. A. (1994). What is welfare economics? a belated answer to a poorly appreciated question. International Journal of Social Economics. 
219. Dunfee, T. W. (2006). A critical perspective of integrative social contracts theory: Recurring criticisms and next generation research topics. Journal of Business Ethics, 68(3), 303-328.

220. Dunfee, T. W., \& Donaldson, T. (1995). Contractarian business ethics: Current status and next steps. Business Ethics Quarterly, 173-186.

221. Dunfee, T. W., Smith, N. C., \& Ross Jr, W. T. (1999). Social contracts and marketing ethics. Journal of marketing, 63(3), 14-32.

222. Dyer, J. S., Fishburn, P. C., Steuer, R. E., Wallenius, J., \& Zionts, S. (1992). Multiple criteria decision making, multiattribute utility theory: the next ten years. Management science, 38(5), 645-654

223. Eddleston, K. A. (2008). Commentary: The prequel to family firm culture and stewardship: The leadership perspective of the founder. Entrepreneurship theory and practice, 32(6), 1055-1061.

224. Eddleston, K. A., \& Kellermanns, F. W. (2007). Destructive and productive family relationships: A stewardship theory perspective. Journal of Business Venturing, 22(4), 545-565.

225. Edwards, F. R., \& Morrison, E. R. (2005). Derivatives and the bankruptcy code: Why the special treatment. Yale J. on Reg., 22, 91.

226. Eisenhardt, K. M. (1988). Agency-and institutional-theory explanations: The case of retail sales compensation. Academy of Management journal, 31(3), 488-511.

227. Eisenhardt, K. M. (1989). Agency theory: An assessment and review. Academy of management review, 14(1), 57-74.

228. Eling, M., \& Schmeiser, H. (2010). Insurance and the credit crisis: Impact and ten consequences for risk management and supervision. The Geneva Papers on Risk and Insurance-Issues and Practice, 35(1), 9-34.

229. Eling, M., Schmeiser, H., \& Schmit, J. T. (2007). The Solvency II process: Overview and critical analysis. Risk management and insurance review, 10(1), 69-85.

230. Ellickson, R. C. (1998). Law and economics discovers social norms. The Journal of Legal Studies, 27(S2), 537-552.

231. Enriques, L. (2003). Bad apples, bad oranges: A comment from old Europe on post-Enron corporate governance reforms. Wake Forest L. Rev., 38, 911.

232. Evers, W. M. (1980). Specialization and the Division of Labor in the Social Thought of Plato and Rousseau. The Journal of Libertarian Studies, 4(1), 45-64.

233. Falvey, R. E., Foster, N., \& Memedovic, O. (2006). The role of intellectual property rights in technology transfer and economic growth: theory and evidence. UNIDO.

234. Fama, E. F. (1980). Agency problems and the theory of the firm. Journal of political economy, 88(2), 288-307.

235. Fama, E. F., \& Jensen, M. C. (1983). Agency problems and residual claims. The journal of law and Economics, 26(2), 327-349.

236. Fama, E. F., \& Jensen, M. C. (1983). Separation of ownership and control. The journal of law and Economics, 26(2), 301-325.

237. Farh, C. I., Lanaj, K., \& Ilies, R. (2017). Resource-based contingencies of when team-member exchange helps member performance in teams. Academy of Management Journal, 60(3), 1117-1137.

238. Faulhaber, A. K., Dittmer, A., Blind, F., Wächter, M. A., Timm, S., Sütfeld, L. R., ... \& König, P. (2019). Human decisions in moral dilemmas are largely described by utilitarianism: Virtual car driving study provides guidelines for autonomous driving vehicles. Science and engineering ethics, 25(2), 399-418.

239. Faunce, W. A. (1965). Automation and the division of labor. Social Problems, 13(2), 149-160.

240. Feder, G., \& Feeny, D. (1991). Land tenure and property rights: Theory and implications for development policy. The World Bank Economic Review, 5(1), 135-153.

241. Feenstra, R. C., \& Hanson, G. H. (2005). Ownership and control in outsourcing to China: Estimating the property-rights theory of the firm. The Quarterly Journal of Economics, 120(2), 729-761. 
242. Fey, C. F., \& Denison, D. R. (2003). Organizational culture and effectiveness: can American theory be applied in Russia?. Organization science, 14(6), 686-706.

243. Fine, L. M. (2010). Altruism and hedonism: A review and discussion of recent findings in the marketing and consumer behavior literature. Business Horizons, 53(3), 241-246.

244. Fink, R. C., Edelman, L. F., Hatten, K. J., \& James, W. L. (2006). Transaction cost economics, resource dependence theory, and customer-supplier relationships. Industrial and Corporate Change, 15(3), 497-529.

245. Fishburn, P. C. (1968). Utility theory. Management science, 14(5), 335-378.

246. Florackis, C. (2005). Internal corporate governance mechanisms and corporate performance: evidence for UK firms. Applied Financial Economics Letters, 1(4), 211-216.

247. Florackis, C., \& Ozkan, A. (2009). Managerial incentives and corporate leverage: evidence from the United Kingdom. Accounting \& Finance, 49(3), 531-553.

248. Foot, P. (1985). Utilitarianism and the Virtues. Mind, 94(374), 196-209.

249. Forcadell, F. J., \& Aracil, E. (2017). European banks' reputation for corporate social responsibility. Corporate Social Responsibility and Environmental Management, 24(1), 1-14.

250. Fox, M. A., \& Hamilton, R. T. (1994). Ownership and diversification: Agency theory or stewardship theory. Journal of Management Studies, 31(1), 69-81.

251. Foxall, G. R., \& Sigurdsson, V. (2013). Consumer behavior analysis: behavioral economics meets the marketplace. The Psychological Record, 63(2), 231-238.

252. Fraedrich, J., Thorne, D. M., \& Ferrell, O. C. (1994). Assessing the application of cognitive moral development theory to business ethics. Journal of Business Ethics, 13(10), 829-838.

253. Franke, G. R., Crown, D. F., \& Spake, D. F. (1997). Gender differences in ethical perceptions of business practices: A social role theory perspective. Journal of applied psychology, 82(6), 920.

254. Frech III, H. E. (1976). The property rights theory of the firm: empirical results from a natural experiment. Journal of Political Economy, 84(1), 143-152.

255. Freeman, R. E., \& Phillips, R. A. (2002). Stakeholder theory: A libertarian defense. Business ethics quarterly, 12(3), 331-349.

256. Freeman, R. E., Harrison, J. S., Wicks, A. C., Parmar, B. L., \& De Colle, S. (2010). Stakeholder theory: The state of the art. Cambridge University Press.

257. Freeman, S. (1994). Utilitarianism, deontology, and the priority of right. Philosophy \& Public Affairs, 23(4),313-349.

258.

259. Freidson, E. (1976). The division of labor as social interaction. Social problems, 23(3), 304-313.

260. Friedman, A. L., \& Miles, S. (2002). Developing stakeholder theory. Journal of management studies, 39(1), 1-21.

261. Froelich, K. A. (1999). Diversification of revenue strategies: Evolving resource dependence in nonprofit organizations. Nonprofit and voluntary sector quarterly, 28(3), 246-268.

262. Furubotn, E. G., \& Pejovich, S. (1972). Property rights and economic theory: a survey of recent literature. Journal of economic literature, 10(4), 1137-1162.

263. Galbi, D. A. (1997). Child labor and the division of labor in the early English cotton mills. Journal of Population Economics, 10(4), 357-375.

264. Galbreath, J. (2005). Which resources matter the most to firm success? An exploratory study of resource-based theory. Technovation, 25(9), 979-987.

265. Gallo, M. A., \& Vilaseca, A. (1996). Finance in family business. Family business review, 9(4), 387-401.

266. Gardberg, N. A., Zyglidopoulos, S. C., Symeou, P. C., \& Schepers, D. H. (2019). The impact of corporate philanthropy on reputation for corporate social performance. Business \& society, 58(6), 1177-1208.

267. Garefalakis, A., Dimitras, A. I., \& Lemonakis, C. (2017). The effect of Corporate Governance Information (CGI) on banksreporting performance. Investment management and financial innovations, (14,№ 2), 63-70.

268. Garnsey, E. (1981). The rediscovery of the division of labor. Theory and Society, 10(3), 337-358. 
269. Gatzert, N., \& Wesker, H. (2012). A comparative assessment of Basel II/III and Solvency II. The Geneva Papers on Risk and Insurance-Issues and Practice, 37(3), 539-570.

270. Gautschi, F. H., \& Jones, T. M. (1998). Enhancing the ability of business students to recognize ethical issues: An empirical assessment of the effectiveness of a course in business ethics. Journal of Business Ethics, 17(2), 205-216.

271. Gençoğlu, Ü. G., \& Ertan, Y. (2012). Muhasebe kalitesini etkileyen faktörler ve Türkiye'deki durum. Muhasebe ve Finansman Dergisi, (53), 1-24.

272. Gerber, J. D., Knoepfel, P., Nahrath, S., \& Varone, F. (2009). Institutional Resource Regimes: Towards sustainability through the combination of property-rights theory and policy analysis. Ecological economics, 68(3), 798-809.

273. Gertler, M. S., \& Wolfe, D. A. (2004). Local social knowledge management: Community actors, institutions and multilevel governance in regional foresight exercises. Futures, 36(1), 45-65.

274. Getz, D., \& Petersen, T. (2005). Growth and profit-oriented entrepreneurship among family business owners in the tourism and hospitality industry. International journal of hospitality management, 24(2), 219-242.

275. Geyskens, I., Steenkamp, J. B. E., \& Kumar, N. (2006). Make, buy, or ally: A transaction cost theory meta-analysis. Academy of management journal, 49(3), 519-543.

276. Ghoshal, S., \& Moran, P. (1996). Bad for practice: A critique of the transaction cost theory. Academy of management Review, 21(1), 13-47.

277. Gibbard, A. F. (1965). Rule-utilitarianism: Merely an illusory alternative?. Australasian Journal of Philosophy, 43(2), 211-220.

278. Gibbs, J. P., \& Browning, H. L. (1966). The division of labor, technology, and the organization of production in twelve countries. American Sociological Review, 81-92.

279. Gibbs, J. P., \& Poston Jr, D. L. (1975). The division of labor: Conceptualization and related measures. Social Forces, 53(3), 468-476.

280. Gibson, K. (2000). The moral basis of stakeholder theory. Journal of business ethics, 245-257.

281. Gide, C. (1898). Has co-operation introduced a new principle into economics?. The Economic Journal, 8(32), 490-511.

282. Gilbert, D. U., \& Behnam, M. (2009). Advancing integrative social contracts theory: A Habermasian perspective. Journal of Business Ethics, 89(2), 215-234.ç

283. Gilbert, D. U., \& Rasche, A. (2007). Discourse ethics and social accountability: The ethics of SA 8000. Business Ethics Quarterly, 17(2), 187-216.

284. Glimcher, P. W., Dorris, M. C., \& Bayer, H. M. (2005). Physiological utility theory and the neuroeconomics of choice. Games and economic behavior, 52(2), 213.

285. Goergen, M., \& Tonks, I. (2019). Introduction to Special Issue on Sustainable Corporate Governance. British Journal of Management, 30(1), 3-9.

286. Goldberg, V. P. (1976). Toward an expanded economic theory of contract. Journal of Economic Issues, 10(1), 45-61.

287. Goncharov, I., Werner, J. R., \& Zimmermann, J. (2006). Does compliance with the German corporate governance code have an impact on stock valuation? An empirical analysis. Corporate Governance: an international review, 14(5), 432-445.

288. Goodhart, C. A. (2002). The organizational structure of banking supervision. Economic Notes, $31(1), 1-32$.

289. Goodpaster, K. E. (1991). Business ethics and stakeholder analysis. Business ethics quarterly, 53-73.

290. Gordon, R. W. (2002). A New Role for Lawyers: The Corporate Counselor after Enron. Conn. L. Rev., 35, 1185.

291. Gordy, M. B., \& Howells, B. (2006). Procyclicality in Basel II: Can we treat the disease without killing the patient?. Journal of financial intermediation, 15(3), 395-417.

292. Gosling, M., \& Huang, H. J. (2009). The fit between integrity and integrative social contracts theory. Journal of Business Ethics, 90(3), 407-417. 
293. Graafland, J. J., \& Eijffinger, S. C. W. (2004). Corporate social responsibility of Dutch companies: Benchmarking, transparency and robustness. De Economist, 152(3), 403-426.

294. Grappi, S., \& Montanari, F. (2011). The role of social identification and hedonism in affecting tourist re-patronizing behaviours: The case of an Italian festival. Tourism management, 32(5), 1128-1140.

295. Graves, S. B., \& Waddock, S. A. (1994). Institutional owners and corporate social performance. Academy of Management journal, 37(4), 1034-1046.

296. Gray, M., \& Lovat, T. (2007). Horse and carriage: Why Habermas's discourse ethics gives virtue a praxis in social work. Ethics and Social Welfare, 1(3), 310-328.

297. Green, R. M. (1993). Business ethics as a postmodern phenomenon. Business Ethics Quarterly, 219-225.

298. Greening, D. W., \& Turban, D. B. (2000). Corporate social performance as a competitive advantage in attracting a quality workforce. Business \& society, 39(3), 254-280.,

299. Greif, A. (1997). Micro theory and recent developments in the study of economic institutions through economic history. Available at SSRN 1243.

300. Griffin, D., Guedhami, O., Kwok, C. C., Li, K., \& Shao, L. (2014). National culture, corporate governance practices, and firm performance. SRN Electronic Journal.

301. Griffin, D., Guedhami, O., Kwok, C. C., Li, K., \& Shao, L. (2017). National culture: The missing country-level determinant of corporate governance. Journal of International Business Studies, 48(6), 740-762.

302. Griffin, J. J., \& Mahon, J. F. (1997). The corporate social performance and corporate financial performance debate: Twenty-five years of incomparable research. Business \& society, 36(1), 5-31.

303. Guiso, L., Sapienza, P., \& Zingales, L. (2015). The value of corporate culture. Journal of Financial Economics, 117(1), 60-76.

304. Gunson, D., \& Collins, C. (1997). From the I to the We: discourse ethics, identity, and the pragmatics of partnership in the west of Scotland. Communication Theory, 7(4), 278-300.

305. Gustafson, A. (2000). Making sense of postmodern business ethics. Business Ethics Quarterly, 10(3), 645-658.

306. Günay, S. G. (2007). The Impact of Managers' and/or Directors' Perceptions of Corporate Governance on The Financial Performances of the Industrial Firms in Turkey: Comparison of the Stockholder and The Stakeholder Governance Models (Doctoral dissertation, Boğaziçi University).

307. Hahn, R. W. (1984). Market power and transferable property rights. The Quarterly Journal of Economics, 99(4), 753-765.

308. Hall, A., Melin, L., \& Nordqvist, M. (2001). Entrepreneurship as radical change in the family business: Exploring the role of cultural patterns. Family business review, 14(3), 193-208.

309. Hall, R. E. (1988). The relation between price and marginal cost in US industry. Journal of political Economy, 96(5), 921-947.

310. Hallstein, D. L. O. B. (1999). A postmodern caring: Feminist standpoint theories, revisioned caring, and communication ethics. Western Journal of Communication (includes Communication Reports), 63(1), 32-56.

311. Hammond, P. J. (1997). Rationality in economics. Rivista internazionale di scienze sociali, 105(3), 247-288.

312. Hammond, P. J. (1997). Rationality in economics. Rivista internazionale di scienze sociali, 105(3), 247-288.

313. Hands, D. W. (2010). Economics, psychology and the history of consumer choice theory. Cambridge Journal of Economics, 34(4), 633-648.

314. Haniffa, R. M., \& Cooke, T. E. (2002). Culture, corporate governance and disclosure in Malaysian corporations. Abacus, 38(3), 317-349.

315. Haniffa, R. M., \& Cooke, T. E. (2005). The impact of culture and governance on corporate social reporting. Journal of accounting and public policy, 24(5), 391-430. 
316. Hansmann, H. (1983). The current state of law-and-economics scholarship. Journal of legal education, 33(2), 217-236.

317. Harnay, S., \& Marciano, A. (2009). Posner, economics and the law: From "law and economics" to an economic analysis of law. Journal of the History of Economic Thought, 31(2), 215-232.

318. Harrod, R. F. (1936). Utilitarianism revised. Mind, 45(178), 137-156.

319. Hart, O., \& Moore, J. (1990). Property Rights and the Nature of the Firm. Journal of political economy, 98(6), 1119-1158.

320. Hart, S. L. (1995). A natural-resource-based view of the firm. Academy of management review, 20(4), 986-1014.

321. Hartley, R., \& Farrell, L. (2002). Can expected utility theory explain gambling?. American Economic Review, 92(3), 613-624.

322. Hartman, L. P., Shaw, B., \& Stevenson, R. (2003). Exploring the ethics and economics of global labor standards: A challenge to integrated social contract theory. Business Ethics Quarterly, 13(2), 193-220.

323. Hasnas, J. (1998). The normative theories of business ethics: A guide for the perplexed. Business Ethics Quarterly, 8(1), 19-42.

324. Healy, P. M., \& Palepu, K. G. (2003). The fall of Enron. Journal of economic perspectives, 17(2), 3-26.

325. Heath, J., \& Norman, W. (2004). Stakeholder theory, corporate governance and public management: what can the history of state-run enterprises teach us in the post-Enron era?. Journal of business ethics, 53(3), 247-265.

326. Heath, J., \& Norman, W. (2004). Stakeholder theory, corporate governance and public management: what can the history of state-run enterprises teach us in the post-Enron era?. Journal of business ethics, 53(3), 247-265.

327. Hendry, J. (2001). Missing the target: Normative stakeholder theory and the corporate governance debate. Business Ethics Quarterly, 159-176.

328. Herring, R. J. (2002). The Basel 2 approach to bank operational risk: Regulation on the wrong track. Journal of Risk Finance, 4(1), 42-46.

329. Hetherington, N. S. (1983). Isaac Newton's influence on Adam Smith's natural laws in economics. Journal of the History of Ideas, 44(3), 497-505.

330. Hill, C. A. (2009). Why did anyone listen to the rating agencies after Enron. J. Bus. \& Tech. L., 4, 283.

331. Hill, C. W. (1990). Cooperation, opportunism, and the invisible hand: Implications for transaction cost theory. Academy of management review, 15(3), 500-513.

332. Hill, C. W., \& Jones, T. M. (1992). Stakeholder囚agency theory. Journal of management studies, 29(2), 131-154.

333. Hill, R. P. (2017). Failure of Ethical Leadership: Implications for Stakeholder Theory and "Anti冈 Stakeholders". Business and Society Review, 122(2), 165-190.

334. Hillman, A. J., \& Dalziel, T. (2003). Boards of directors and firm performance: Integrating agency and resource dependence perspectives. Academy of Management review, 28(3), 383-396.

335. Hillman, A. J., Cannella, A. A., \& Paetzold, R. L. (2000). The resource dependence role of corporate directors: Strategic adaptation of board composition in response to environmental change. Journal of Management studies, 37(2), 235-256.

336. Hillman, A. J., Withers, M. C., \& Collins, B. J. (2009). Resource dependence theory: A review. Journal of management, 35(6), 1404-1427.

337. Hobbs, D., Hadfield, P., Lister, S., \& Winlow, S. (2002). 'Door lore': the art and economics of intimidation. The British journal of criminology, 42(2), 352-370.

338. Hodgson, G. M. (1993). Institutional economics: surveying the 'old'and the 'new'. Metroeconomica, 44(1), 1-28.

339. Hodgson, G. M. (1998). The approach of institutional economics. Journal of economic literature, 36(1), 166-192. 
340. Hodgson, G. M. (2000). What is the essence of institutional economics?. Journal of economic issues, 34(2), 317-329.

341. Hodgson, G. M. (2001). Frontiers of institutional economics. New Political Economy, 6(2), 245-253.

342. Hodgson, G. M. (2007). Evolutionary and institutional economics as the new mainstream?. Evolutionary and Institutional Economics Review, 4(1), 7-25.

343. Hodgson, G. M. (2009). Institutional economics into the twenty-first century. Studi e Note di Economia, 14(1), 3-26.

344. Hoffman, E., \& Spitzer, M. L. (1985). Experimental law and economics: An introduction. Columbia Law Review, 85(5), 991-1036.

345. Hofstede, G. (1983). National cultures in four dimensions: A research-based theory of cultural differences among nations. International Studies of Management \& Organization, 13(1-2), 46-74.

346. Hofstede, G. (1994). Management scientists are human. Management science, 40(1), 4-13.

347. Hofstede, G. (1994). The business of international business is culture. International business review, 3(1), 1-14.ç

348. Hofstede, G. (2011). Dimensionalizing cultures: The Hofstede model in context. Online readings in psychology and culture, 2(1), 8.

349. Hofstede, G., \& Bond, M. H. (1988). The Confucius connection: From cultural roots to economic growth. Organizational dynamics, 16(4), 5-21.

350. Hofstede, G., Neuijen, B., Ohayv, D. D., \& Sanders, G. (1990). Measuring organizational cultures: A qualitative and quantitative study across twenty cases. Administrative science quarterly, 286-316.

351. Holzmüller, I. (2009). The United States RBC standards, Solvency II and the Swiss solvency test: a comparative assessment. The Geneva Papers on Risk and Insurance-Issues and Practice, 34(1), 56-77.

352. Hoopes, D. G., Madsen, T. L., \& Walker, G. (2003). Guest editors' introduction to the special issue: why is there a resource区based view? Toward a theory of competitive heterogeneity. Strategic management journal, 24(10), 889-902.

353. Horwitz, M. J. (1980). Law and economics: science or politics?. Hofstra Law Review, 8(4), 2.

354. Hosmer, L. T. (1995). Trust: The connecting link between organizational theory and philosophical ethics. Academy of management Review, 20(2), 379-403.

355. Hosmer, L. T., \& Kiewitz, C. (2005). Organizational justice: A behavioral science concept with critical implications for business ethics and stakeholder theory. Business Ethics Quarterly, 15(1), 67-91.

356. Hosseini, H. (1998). Seeking the roots of Adam Smith's division of labor in medieval Persia. History of Political Economy, 30(4), 653.

357. https://www.bddk.org.tr/WebSitesi/turkce/Basel/1317Pillar-3.pdf, Erişim Tarihi: 15.12.2017.

358. https://www.bddk.org.tr/WebSitesi/turkce/Basel/8742sorularla_basel_iii_29_11_2010_.pdf,

359. Erişim Tarihi: 05.12.2017.

360. https://www.tbb.org.tr/Dosyalar/Arastirma_ve_Raporlar/Basel.doc, Erişim Tarihi: 05.12.2017. 361.

362. https://www.tbb.org.tr/Dosyalar/Arastirma_ve_Raporlar/Basel.doc, Erişim Tarihi: 05.12.2017. 363.

364. Hughes, M., Powell, T. H., Chung, L., \& Mellahi, K. (2017). Institutional and resource区based explanations for subsidiary performance. British Journal of Management, 28(3), 407-424.

365. Husted, B. W. (1999). A critique of the empirical methods of integrative social contracts theory. Journal of Business Ethics, 20(3), 227-235.

366. Husted, B. W. (2000). A contingency theory of corporate social performance. Business \& society, 39(1), 24-48.

367. Hutchings, K. (2007). Feminist ethics and political violence. International politics, 44(1), 90-106. 
368. Hutchison, T. W. (1984). Institutionalist economics old and new. Zeitschrift für die gesamte Staatswissenschaft/Journal of Institutional and Theoretical Economics, (H. 1), 20-29.

369. Hynes, R., \& Posner, E. A. (2002). The law and economics of consumer finance. American Law and Economics Review, 4(1), 168-207.

370. Hyytinen, A., \& Takalo, T. (2002). Enhancing bank transparency: A re-assessment. Review of Finance, 6(3), 429-445.

371. Ingram, P., \& Simons, T. (1995). Institutional and resource dependence determinants of responsiveness to work-family issues. Academy of Management Journal, 38(5), 1466-1482.

372. Inmaculada, C. (2006). Ethics and banking. International Advances in Economic Research, $12,43-50$.

373. Jackson, W. A. (1996). Cultural materialism and institutional economics. Review of Social Economy, 54(2), 221-244.

374. Jawahar, I. M., \& McLaughlin, G. L. (2001). Toward a descriptive stakeholder theory: An organizational life cycle approach. Academy of management review, 26(3), 397-414.

375. Jensen, M. C. (1986). Agency costs of free cash flow, corporate finance, and takeovers. The American economic review, 76(2), 323-329.

376. Jensen, M. C. (1991). Corporate control and the politics of finance. Journal of applied corporate finance, 4(2), 13-34.

377. Jensen, M. C. (1994). Self囚interest, altruism, incentives, and agency theory. Journal of applied corporate finance, $7(2), 40-45$.

378. Jensen, M. C. (2002). Value maximization, stakeholder theory, and the corporate objective function. Business ethics quarterly, 235-256.

379. Jensen, M. C., \& Murphy, K. J. (1990). CEO incentives-It's not how much you pay, but how. Journal of Applied Corporate Finance, 3(3), 36-49.

380. Jensen, M. C., \& Murphy, K. J. (1990). Performance pay and top-management incentives. Journal of political economy, 98(2), 225-264.

381. Jensen, M. C., \& Smith, C. W. (2000). Stockholder, manager, and creditor interests: Applications of agency theory. Theory of the Firm, 1(1).

382. Jizi, M. I., Salama, A., Dixon, R., \& Stratling, R. (2014). Corporate governance and corporate social responsibility disclosure: Evidence from the US banking sector. Journal of business ethics, 125(4), 601-615.

383. Johanson, J., \& Mattsson, L. G. (1987). Interorganizational relations in industrial systems: a network approach compared with the transaction-cost approach. International Studies of Management \& Organization, 17(1), 34-48.

384. Johnsen, D. B. (2009). The ethics of "commercial bribery": Integrative social contract theory meets transaction cost economics. Journal of Business Ethics, 88(4), 791-803.

385. Johnson Jr, B. L. (1995). Resource Dependence Theory: A Political Economy Model of Organizations.

386. Jones, C. (2003). As if Business Ethics were Possible,within Such Limits'... Organization, 10(2), 223-248.

387. Jones, D. (2000). Emerging problems with the Basel Capital Accord: Regulatory capital arbitrage and related issues. Journal of Banking \& Finance, 24(1-2), 35-58.

388. Jones, G. R., \& Butler, J. E. (1992). Managing internal corporate entrepreneurship: An agency theory perspective. Journal of management, 18(4), 733-749.

389. Jones, M. L. (2007). Hofstede-culturally questionable?

390. Jones, T. M. (1995). Instrumental stakeholder theory: A synthesis of ethics and economics. Academy of management review, 20(2), 404-437.

391. Jones, T. M., \& Wicks, A. C. (1999). Convergent stakeholder theory. Academy of management review, 24(2), 206-221.

392. Jonsson, A., \& Voorneveld, M. (2018). The limit of discounted utilitarianism. Theoretical Economics, 13(1), 19-37. 
393. Joskow, P. L. (2002). Transaction cost economics, antitrust rules, and remedies. Journal of Law, Economics, and Organization, 18(1), 95-116.

394. Kahn, W. A. (1990). Toward an agenda for business ethics research. Academy of Management Review, 15(2), 311-328.

395. Kahneman, D. (2003). A psychological perspective on economics. American economic review, 93(2), 162-168.

396. Kahneman, D. (2003). Maps of bounded rationality: Psychology for behavioral economics. American economic review, 93(5), 1449-1475.

397. Kahneman, D. (2003). Maps of bounded rationality: Psychology for behavioral economics. American economic review, 93(5), 1449-1475.

398. Kaptein, M. (2017). The battle for business ethics: A struggle theory. Journal of Business Ethics, 144(2), 343-361.

399. Karakaya, M. (2010). Kobi’lerin Küresel Ekonomik İklime Uyumunda Uluslararası Finansal Raporlama Standartları. Muhasebe Ve Vergi Uygulamalari Dergisi (Muvu)/Journal Of Accounting \& Taxation Studies (Jats), 3(2).

400. Karr, H. W., \& Geisler, M. A. (1956). A fruitful application of static marginal analysis. Management Science, 2(4), 313-326.

401. Kelemen, M., \& Peltonen, T. (2001). Ethics, morality and the subject: the contribution of Zygmunt Bauman and Michel Foucault topostmodern'business ethics. Scandinavian Journal of Management, 17(2), 151-166.

402. Kelman, M. G. (1983). Misunderstanding social life: a critique of the core premises of law and economics. J. Legal Educ., 33, 274.

403. Kemper, T. D. (1972). The division of labor: a post-Durkheimian analytical view. American Sociological Review, 739-753.

404. Kenworthy, L. (2006). Institutional coherence and macroeconomic performance. SocioEconomic Review, 4(1), 69-91.

405. Kessler, D. (2014). Why (re) insurance is not systemic. Journal of Risk and Insurance, 81(3), 477-488.

406. Key, S. (1999). Toward a new theory of the firm: a critique of stakeholder "theory". Management decision.

407. Kim, J., \& Mahoney, J. T. (2005). Property rights theory, transaction costs theory, and agency theory: an organizational economics approach to strategic management. Managerial and decision economics, 26(4), 223-242.

408. King, M. R., \& Sinclair, T. J. (2003). Private actors and public policy: a requiem for the new Basel Capital Accord. International Political Science Review, 24(3), 345-362.

409. King, R. G., \& Levine, R. (1993). Finance, entrepreneurship and growth. Journal of Monetary economics, 32(3), 513-542.

410. Kirkpatrick, G. (2009). The corporate governance lessons from the financial crisis. OECD Journal: Financial Market Trends, 61-87.

411. Kitch, E. W. (1980). The law and economics of rights in valuable information. The Journal of Legal Studies, 9(4), 683-723.

412. Klein, A. (2003). Likely effects of stock exchange governance proposals and Sarbanes-Oxley on corporate boards and financial reporting. Accounting Horizons, 17(4), 343-355.

413. Klein, B. (1980). Transaction cost determinants of" unfair" contractual arrangements. The American economic review, 70(2), 356-362.

414. Klein, B., \& Saft, L. F. (1985). The law and economics of franchise tying contracts. The Journal of Law and Economics, 28(2), 345-361.

415. Kluvers, R., \& Tippett, J. (2011, December). An exploration of stewardship theory in a notfor-profit organisation. In Accounting Forum (Vol. 35, No. 4, pp. 275-284). Taylor \& Francis.

416. Kochan, T. A., \& Rubinstein, S. A. (2000). Toward a stakeholder theory of the firm: The Saturn partnership. Organization science, 11(4), 367-386. 
417. Koehn, D. (1995). A role for virtue ethics in the analysis of business practice. Business Ethics Quarterly, 533-539.

418. Koehn, D. (1998). Virtue ethics, the firm, and moral psychology. Business Ethics Quarterly, 8(3), 497-513.

419. Korobkin, R. B., \& Ulen, T. S. (2000). Law and behavioral science: Removing the rationality assumption from law and economics. Calif. L. Rev., 88, 1051.

420. Kotz, H. H., \& Schmidt, R. H. (2017). Corporate governance of banks: A German alternative to the" standard model" (No. 45). SAFE White Paper.

421. Krier, J. E. (2009). Evolutionary theory and the origin of property rights. Cornell L. Rev., 95, 139.

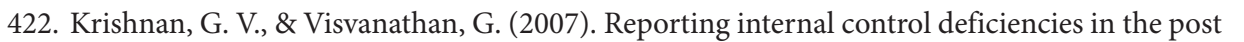
Sarbanes $\bigotimes$ Oxley era: the role of auditors and corporate governance. International Journal of Auditing, 11(2), 73-90.

423. Kropp, S. H. (2007). Corporate Governance, Executive Compensation, Corporate Performance, and Worker Rights in Bankruptcy: Some Lessons from Game Theory. DePaul L. Rev., 57, 1.

424. Kunz, A. H., \& Pfaff, D. (2002). Agency theory, performance evaluation, and the hypothetical construct of intrinsic motivation. Accounting, organizations and society, 27(3), 275-295.

425. Kushner, K. E., \& Morrow, R. (2003). Grounded theory, feminist theory, critical theory: Toward theoretical triangulation. Advances in Nursing Science, 26(1), 30-43.

426. Kusnadi, Y. (2004, November). Corporate governance mechanisms and corporate cash holdings. In EFA 2005 Moscow Meetings Paper.

427. Kusnadi, Y. (2011). Do corporate governance mechanisms matter for cash holdings and firm value?. Pacific-Basin Finance Journal, 19(5), 554-570.

428. Labovitz, S., \& Gibbs, J. P. (1964). Urbanization, technology, and the division of labor: Further evidence. Pacific Sociological Review, 7(1), 3-9.

429. Lan, L. L., \& Heracleous, L. (2010). Rethinking agency theory: The view from law. Academy of management review, 35(2), 294-314.

430. Landes, W. M., \& Posner, R. A. (1993). The influence of economics on law: A quantitative study. The Journal of Law and Economics, 36(1, Part 2), 385-424.

431. Langevoort, D. C. (2003). Managing the Expectations Gap in Inventor Protection: The SEC and the Post-Enron Reform Agenda. Vill. L. Rev., 48, 1139.

432. Langlois, R. N. (1992). Transaction-cost economics in real time. Industrial and corporate change, 1(1), 99-127.

433. Laplume, A. O., Sonpar, K., \& Litz, R. A. (2008). Stakeholder theory: Reviewing a theory that moves us. Journal of management, 34(6), 1152-1189.

434. Lastra, R. (2012). Accountability and Governance: Banking Union Proposals. DSF Policy Paper No30.

435. Lavezzi, A. M. (2001). Division of labor and economic growth: from Adam Smith to Paul Romer and beyond. manuskript, University of Pisa.

436. Lawson, T. (2005). The nature of institutional economics. Evolutionary and Institutional Economics Review, 2(1), 7-20.

437. Lee, K. (1999). Corporate Governance and Growth in the Korean Chaebols: A Microeconomic Foundation for the 1997 Crisis. Seoul National Univ., mimeo.

438. Lee, P. M., \& O’neill, H. M. (2003). Ownership structures and R\&D investments of US and Japanese firms: Agency and stewardship perspectives. Academy of Management Journal, 46(2), 212-225.

439. Leech, D., \& Manjón, M. C. (2003). Corporate governance and game theoretic analyses of shareholder power: the case of Spain. Applied Economics, 35(7), 847-858.

440. Leeson, P. T. (2007). An-arrgh-chy: The law and economics of pirate organization. Journal of political economy, 115(6), 1049-1094. 
441. Lehmann, A. P., \& Hofmann, D. M. (2010). Lessons learned from the financial crisis for risk management: Contrasting developments in insurance and banking. The Geneva Papers on Risk and Insurance-Issues and Practice, 35(1), 63-78.

442. Leibenstein, H. (1968). Entrepreneurship and development. The American Economic Review, 58(2), $72-83$.

443. Leibenstein, H. (1983). Property rights and X-efficiency: Comment. The American Economic Review, 73(4), 831-842.

444. Lemmon, M. L., \& Lins, K. V. (2003). Ownership structure, corporate governance, and firm value: Evidence from the East Asian financial crisis. The journal of finance, 58(4), 1445-1468.

445. Leppälä, S., \& Desrochers, P. (2010). The division of labor need not imply regional specialization. Journal of Economic Behavior \& Organization, 74(1-2), 137-147.

446. Lewin, S. B. (1996). Economics and psychology: Lessons for our own day from the early twentieth century. Journal of Economic Literature, 34(3), 1293-1323.

447. Lewis, P. V. (1985). Defining 'business ethics': Like nailing jello to a wall. Journal of Business ethics, 4(5), 377-383.

448. Li, D. D. (1996). A theory of ambiguous property rights in transition economies: The case of the Chinese non-state sector. Journal of Comparative Economics, 23(1), 1-19.

449. Li, H., Zhang, H., Tsai, S. B., \& Qiu, A. (2017). China’s insurance regulatory reform, corporate governance behavior and insurers' governance effectiveness. International journal of environmental research and public health, 14(10), 1238.

450. Li, J., \& Harrison, J. R. (2008). Corporate governance and national culture: a multi冈country study. Corporate Governance: The international journal of business in society.

451. Li, J., \& Harrison, J. R. (2008). National culture and the composition and leadership structure of boards of directors. Corporate Governance: An International Review, 16(5), 375-385.

452. Liang, T. P., \& Huang, J. S. (1998). An empirical study on consumer acceptance of products in electronic markets: a transaction cost model. Decision support systems, 24(1), 29-43.

453. Licht, A. N., Goldschmidt, C., \& Schwartz, S. H. (2001). Culture, law, and finance: cultural dimensions of corporate governance laws. Available at SSRN 267190.

454. Licht, A. N., Goldschmidt, C., \& Schwartz, S. H. (2005). Culture, law, and corporate governance. International review of law and economics, 25(2), 229-255.

455. Liebhafsky, H. H. (1987). Law and economics from different perspectives. Journal of Economic Issues, 21(4), 1809-1836.

456. Liebwein, P. (2006). Risk models for capital adequacy: Applications in the context of solvency II and beyond. The Geneva Papers on Risk and Insurance-Issues and Practice, 31(3), 528-550.

457. Liedtke, P. M. (2007). What's insurance to a modern economy?. The Geneva Papers on Risk and Insurance-Issues and Practice, 32(2), 211-221.

458. Limbs, E. C., \& Fort, T. L. (2000). Nigerian business practices and their interface with virtue ethics. Journal of Business Ethics, 169-179.

459. Linder, U., \& Ronkainen, V. (2004). Solvency II-towards a new insurance supervisory system in the EU. Scandinavian Actuarial Journal, 2004(6), 462-474.

460. Lins, K., \& Servaes, H. (1999). International evidence on the value of corporate diversification. The Journal of Finance, 54(6), 2215-2239.

461. Linsley, P. M., \& Shrives, P. J. (2005). Transparency and the disclosure of risk information in the banking sector. Journal of Financial regulation and Compliance, 13(3), 205-214.

462. Lipnicka, M., \& Verhoeven, J. C. (2017). The application of new institutionalism and the resource dependence theory for studying changes In universities within Europe. Roczniki Nauk Społecznych, 42(4), 7-30.

463. Logan, M. S. (2000). Using agency theory to design successful outsourcing relationships. The International Journal of Logistics Management.

464. Lubatkin, M. H. (2005). A theory of the firm only a microeconomist could love. Journal of Management Inquiry, 14(2), 213-216. 
465. Lucas, L. A. (2001). Integrative social contracts theory: Ethical implications of marketing credit cards to US college students. American Business Law Journal, 38(2), 413-440.

466. Lyons, D. (1972). Rawls versus utilitarianism. The Journal of Philosophy, 69(18), 535-545.

467. Macey, J. R., \& O'hara, M. (1997). The law and economics of best execution. Journal of Financial Intermediation, 6(3), 188-223.

468. Macher, J. T., \& Richman, B. D. (2008). Transaction cost economics: An assessment of empirical research in the social sciences. Business and politics, 10(1), 1-63.

469. Mackenzie, C. (2004). Moral Sanctions. Journal of Corporate Citizenship, (15).ç

470. MacLeod, W. B. (2007). Can contract theory explain social preferences?. American Economic Review, 97(2), 187-192.

471. Macneil, I. R. (1999). Relational contract theory: challenges and queries. Nw. UL Rev., 94, 877.

472. Madhok, A. (2002). Reassessing the fundamentals and beyond: Ronald Coase, the transaction cost and resource区based theories of the firm and the institutional structure of production. Strategic management journal, 23(6), 535-550.

473. Mahoney, J. T., Huff, A. S., \& Huff, J. O. (1994). Toward a new social contract theory in organization science. Journal of Management Inquiry, 3(2), 153-168.

474. Mainardes, E. W., Alves, H., \& Raposo, M. (2011). Stakeholder theory: issues to resolve. Management decision, 49(2), 226-252.

475. Maital, S. (2004). Daniel Kahneman: On redefining rationality. The Journal of Socio-Economics.

476. Malatesta, D., \& Smith, C. R. (2014). Lessons from resource dependence theory for contemporary public and nonprofit management. Public Administration Review, 74(1), 14-25.

477. Manganaris, P., Beccalli, E., \& Dimitropoulos, P. (2017). Bank transparency and the crisis. The British Accounting Review, 49(2), 121-137.

478. Manne, H. G. (1967). Our two corporation systems: Law and economics. Virginia Law Review, 259-284.

479. Marengo, L., \& Dosi, G. (2005). Division of labor, organizational coordination and market mechanisms in collective problem-solving. Journal of Economic Behavior \& Organization, 58(2), 303-326.

480. Marens, R., \& Wicks, A. (1999). Getting real: Stakeholder theory, managerial practice, and the general irrelevance of fiduciary duties owed to shareholders. Business Ethics Quarterly, 9(2), 273-293.

481. Marnburg, E. (2001). The questionable use of moral development theory in studies of business ethics: Discussion and empirical findings. Journal of Business Ethics, 32(4), 275-283.

482. Mason, E. S. (1937). Monopoly in law and economics. The Yale Law Journal, 47(1), 34-49.

483. Masulis, R. W., Wang, C., \& Xie, F. (2007). Corporate governance and acquirer returns. The Journal of Finance, 62(4), 1851-1889.

484. Matouschek, N. (2004). Ex post inefficiencies in a property rights theory of the firm. Journal of Law, Economics, and organization, 20(1), 125-147.

485. Mattingly, C. (2012). Two virtue ethics and the anthropology of morality. Anthropological Theory, 12(2), 161-184.

486. Mattingly, J. E. (2017). Corporate social performance: A review of empirical research examining the corporation-society relationship using Kinder, Lydenberg, Domini social ratings data. Business \& Society, 56(6), 796-839.

487. Mayer, C. (1998). Financial systems and corporate governance: a review of the international evidence. Journal of Institutional and Theoretical Economics (JITE)/Zeitschrift für die gesamte Staatswissenschaft, 144-165.

488. Mayer, D., \& Cava, A. (1995). Social contract theory and gender discrimination: Some reflections on the Donaldson/Dunfee model. Business Ethics Quarterly, 257-270.

489. McCarthy, D., \& Puffer, S. (2002). Corporate Governance in Russia:: towards a European, US, or Russian Model?. European Management Journal, 20(6), 630-640.

490. McCloskey, H. J. (1957). An examination of restricted utilitarianism. The Philosophical Review, 466-485. 
491. McCloskey, H. J. (1957). An examination of restricted utilitarianism. The Philosophical Review, 466-485.

492. McKnight, P. J., \& Weir, C. (2009). Agency costs, corporate governance mechanisms and ownership structure in large UK publicly quoted companies: A panel data analysis. The quarterly review of economics and finance, 49(2), 139-158.

493. McNay, L. (2003). Agency, anticipation and indeterminacy in feminist theory. Feminist Theory, 4(2), 139-148.

494. McNulty, P. J. (1973). Adam Smith's concept of labor. Journal of the History of Ideas, 345-366.

495. McWilliams, A., \& Siegel, D. S. (2011). Creating and capturing value: Strategic corporate social responsibility, resource-based theory, and sustainable competitive advantage. Journal of Management, 37(5), 1480-1495.

496. McWilliams, A., Van Fleet, D. D., \& Cory, K. D. (2002). Raising rivals' costs through political strategy: An extension of resource区based theory. Journal of Management Studies, 39(5), 707-724.

497. Meisenbach, R. J. (2006). Habermas's discourse ethics and principle of universalization as a moral framework for organizational communication. Management Communication Quarterly, 20(1), 39-62.

498. Melé, D. (2009). Integrating personalism into virtue-based business ethics: The personalist and the common good principles. Journal of Business Ethics, 88(1), 227-244.

499. Merrill, T. W., \& Smith, H. E. (2001). What happened to property in law and economics. Yale LJ, 111, 357.

500. Merritt, M. (2000). Virtue ethics and situationist personality psychology. Ethical theory and moral practice, 3(4), 365-383.

501. Meurer, M. J. (2004). Law, Economics, and the Theory of the Firm. Buff. L. Rev., 52, 727.

502. Miles, S. (2017). Stakeholder theory classification: A theoretical and empirical evaluation of definitions. Journal of Business Ethics, 142(3), 437-459.

503. Milhaupt, C. J. (1996). A relational theory of Japanese corporate governance: Contract, culture, and the rule of law. Harv. Int'l. LJ, 37, 3.

504. Miller, C. (2009). Social psychology, mood, and helping: Mixed results for virtue ethics. The Journal of Ethics, 13(2-3), 145-173.

505. Miller, D. (1983). The correlates of entrepreneurship in three types of firms. Management science, 29(7), 770-791.

506. Miller, D., \& Le Breton-Miller, I. (2006). Family governance and firm performance: Agency, stewardship, and capabilities. Family business review, 19(1), 73-87.

507. Miller, D., Steier, L., \& Le Breton-Miller, I. (2003). Lost in time: Intergenerational succession, change, and failure in family business. Journal of business venturing, 18(4), 513-531.

508. Miller, J. L. (2002). The board as a monitor of organizational activity: The applicability of agency theory to nonprofit boards. Nonprofit management and leadership, 12(4), 429-450.

509. Mingers, J. (2011). Ethics and OR: Operationalising discourse ethics. European Journal of Operational Research, 210(1), 114-124.

510. Mingers, J., \& Walsham, G. (2010). Toward ethical information systems: the contribution of discourse ethics. Mis Quarterly, 34(4), 833-854.

511. Mitchell, L. E. (2003). The Sarbanes-Oxley Act and the reinvention of corporate governance. Vill. L. Rev., 48, 1189.

512. Mitchell, R. K., Agle, B. R., \& Wood, D. J. (1997). Toward a theory of stakeholder identification and salience: Defining the principle of who and what really counts. Academy of management review, 22(4), 853-886.

513. Mitton, T. (2002). A cross-firm analysis of the impact of corporate governance on the East Asian financial crisis. Journal of financial economics, 64(2), 215-241.

514. Mohammed, S. A. S. A. N., \& Muhammed, J. (2017). The relationship between agency theory, stakeholder theory and Shariah supervisory board in Islamic banking. Humanomics. 
515. Moh'd, M. A., Perry, L. G., \& Rimbey, J. N. (1995). An investigation of the dynamic relationship between agency theory and dividend policy. Financial Review, 30(2), 367-385.

516. Moncarz, E. S., Moncarz, R., Cabello, A., \& Moncarz, B. (2006). The rise and collapse of enron: Financial innovation, errors and lessons. Contaduría y Administración, (218), 17-37.

517. Moore, G. (2005). Corporate character: Modern virtue ethics and the virtuous corporation. Business Ethics Quarterly, 15(4), 659-685.

518. Morris, R. D. (1987). Signalling, agency theory and accounting policy choice. Accounting and business Research, 18(69), 47-56.

519. Morse, J. (1999). The missing link between virtue theory and business ethics. Journal of Applied Philosophy, 16(1), 47-58.

520. Mouzas, S., \& Blois, K. (2008). Relational contract theory: confirmations and contradictions. In the Proceedings of 24th IMP Conference.

521. Mouzas, S., \& Blois, K. (2008). Relational contract theory: confirmations and contradictions. In the Proceedings of 24th IMP Conference.

522. Mullineux, A. W. A. (2010). Financial innovation and social welfare. Journal of Financial Regulation and Compliance.

523. Mupepi, M. G. (2014). Can the division of labor be re-engineered to advance organizational dynamism?. Sage Open, 4(2), 2158244014536404.

524. Murphy, P. E. (1999). Character and virtue ethics in international marketing: An agenda for managers, researchers and educators. Journal of Business Ethics, 18(1), 107-124.

525. Murphy, P. E., Laczniak, G. R., \& Wood, G. (2007). An ethical basis for relationship marketing: a virtue ethics perspective. European journal of marketing.

526. Muth, M., \& Donaldson, L. (1998). Stewardship theory and board structure: A contingency approach. Corporate Governance: An International Review, 6(1), 5-28.

527. Myers, P. M., \& Ziegenfuss, D. E. (2006). Audit committee pre®Enron efforts to increase the effectiveness of corporate governance. Corporate Governance: The international journal of business in society.

528. Narveson, J. (1967). Utilitarianism and new generations. Mind, 76(301), 62-72.

529. Nason, R. S., Bacq, S., \& Gras, D. (2018). A behavioral theory of social performance: Social identity and stakeholder expectations. Academy of Management Review, 43(2), 259-283.

530. Neal, Z., Neal, J. W., Mills, K., \& Lawlor, J. (2018). Making or buying evidence: Using transaction cost economics to understand decision making in public school districts. Evidence \& policy: a journal of research, debate and practice, 14(4), 707-724.

531. Negishi, T. (2000). Adam Smith's division of labor and structural changes. Structural Change and Economic Dynamics, 11(1-2), 5-11.

532. Nemati, A. R., Bhatti, A. M., Maqsal, M., Mansoor, I., \& Naveed, F. (2010). Impact of resource based view and resource dependence theory on strategic decision making. International Journal of Business and Management, 5(12), 110.

533. Ng, Y. K. (1990). Welfarism and utilitarianism: a rehabilitation. Utilitas, 2(2), 171-193.

534. Nielson, D. L., \& Tierney, M. J. (2003). Delegation to international organizations: Agency theory and World Bank environmental reform. International organization, 57(2), 241-276.

535. Nilakant, V., \& Rao, H. (1994). Agency theory and uncertainty in organizations: An evaluation. Organization studies, 15(5), 649-672.

536. Njegomir, V., \& Tepavac, R. (2014). Corporate governance in insurance companies. Management: Journal of Sustainable Business and Management Solutions in Emerging Economies, 19(71), 81-95.

537. Noland, J., \& Phillips, R. (2010). Stakeholder engagement, discourse ethics and strategic management. International Journal of Management Reviews, 12(1), 39-49.

538. Nussbaum, M. C. (1999). Virtue ethics: A misleading category?. The Journal of Ethics, 3(3), 163-201.

539. O'Hara, M. (1981). Property rights and the financial firm. The Journal of Law and Economics, 24(2), 317-332. 
540. Ojo, M. (2010). Basel III and responding to the recent Financial Crisis: progress made by the Basel Committee in relation to the need for increased bank capital and increased quality of loss absorbing capital.

541. Olavarrieta, S., \& Ellinger, A. E. (1997). Resource区based theory and strategic logistics research. International Journal of Physical Distribution \& Logistics Management.

542. Olsen, T. D. (2017). Political stakeholder theory: The state, legitimacy, and the ethics of microfinance in emerging economies. Business Ethics Quarterly, 27(1), 71-98.

543. Olson, P. D., Zuiker, V. S., Danes, S. M., Stafford, K., Heck, R. K., \& Duncan, K. A. (2003). The impact of the family and the business on family business sustainability. Journal of business venturing, 18(5), 639-666.

544. Orts, E. W., \& Strudler, A. (2002). The ethical and environmental limits of stakeholder theory. Business Ethics Quarterly, 215-233.

545. Ostrom, E. (2008). Institutions and the Environment. Economic affairs, 28(3), 24-31.

546. Ostrom, E., \& Basurto, X. (2011). Crafting analytical tools to study institutional change. Journal of institutional economics, 7(3), 317-343.

547. Ostrom, E., \& Hess, C. (2000). Private and common property rights. In Encyclopedia of law and economics. Edward Elgar Publishing Limited.

548. Ozkan, N. (2007). Do corporate governance mechanisms influence CEO compensation? An empirical investigation of UK companies. Journal of multinational financial management, 17(5), 349-364.

549. Paavola, J. (2007). Institutions and environmental governance: A reconceptualization. Ecological economics, 63(1), 93-103.

550. Pagano, M., \& Volpin, P. F. (2005). The political economy of corporate governance. American economic review, 95(4), 1005-1030.

551. Parker, M. (1998). Business ethics and social theory: Postmodernizing the ethical. British Journal of Management, 9, 27-36.ç

552. Parkhe, A. (1993). Strategic alliance structuring: A game theoretic and transaction cost examination of interfirm cooperation. Academy of management journal, 36(4), 794-829.

553. Partnoy, F., \& Thomas, R. S. (2007). Gap filling, hedge funds, and financial innovation.

554. Parton, N. (2003). Rethinking professional practice: The contributions of social constructionism and the feminist 'ethics of care'. British journal of social work, 33(1), 1-16.

555. Pastoriza, D., \& Ariño, M. A. (2008, June). When agents become stewards: Introducing learning in the stewardship theory. In 1st IESE Conference," Humanizing the Firm \& Management Profession", Barcelona, IESE Business School.

556. Paulet, E. (2011). Banking ethics. Corporate Governance: The international journal of business in society.

557. Pearson, A. W., \& Marler, L. E. (2010). A leadership perspective of reciprocal stewardship in family firms. Entrepreneurship Theory and Practice, 34(6), 1117-1124.

558. Pearson, H. (2000). Homo economicus goes native, 1859-1945: The rise and fall of primitive economics. History of Political Economy, 32(4), 933-989.

559. Pejovich, S. (1971). Towards a general theory of property rights. Zeitschrift für Nationalökonomie/Journal of Economics, (H. 1/2), 141-155.

560. Pejovich, S. (1972). Towards an economic theory of the creation and specification of property rights. Review of Social Economy, 30(3), 309-325.

561. Perelman, M. (2010). Adam Smith: Class, labor, and the industrial revolution. Journal of Economic Behavior \& Organization, 76(3), 481-496.

562. Pérez, A., Martínez, P., \& Del Bosque, I. R. (2013). The development of a stakeholder-based scale for measuring corporate social responsibility in the banking industry. Service Business, 7(3), 459-481.

563. Peteraf, M. A. (1993). The cornerstones of competitive advantage: a resourcebased view. Strategic management journal, 14(3), 179-191.

564. Pettit, P. (1987). Universalizability without utilitarianism. Mind, 96(381), 74-82. 
565. Pfeifer, D., \& Strassburger, D. (2008). Solvency II: stability problems with the SCR aggregation formula. Scandinavian actuarial journal, 2008(1), 61-77.

566. Phan, T. H. D., Brouwer, R., \& Davidson, M. D. (2017). A global survey and review of the determinants of transaction costs of forestry carbon projects. Ecological economics, 133, 1-10.

567. Philippon, T. (2006). Corporate governance over the business cycle. Journal of Economic Dynamics and Control, 30(11), 2117-2141.

568. Phillips, R. A. (1997). Stakeholder theory and a principle of fairness. Business Ethics Quarterly, $7(1), 51-66$.

569. Phillips, R. A., \& Johnson-Cramer, M. E. (2006). Ties that unwind: Dynamism in integrative social contracts theory. Journal of Business Ethics, 68(3), 283-302.

570. Phillips, R., Freeman, R. E., \& Wicks, A. C. (2003). What stakeholder theory is not. Business ethics quarterly, 13(4), 479-502.

571. Pigé, B. (2002). Stakeholder theory and corporate governance: the nature of the board information. Management: journal of contemporary management issues, 7(1), 1-17.

572. Plosser, C. I. (2009). Financial econometrics, financial innovation, and financial stability. Journal of Financial Econometrics, 7(1), 3-11.

573. Ponce, J. (2010). A normative analysis of banking supervision: Independence, legal protection and accountability. Money Affairs, 23(2), 141-181.

574. Pooser, D. M., Wang, P., \& Barrese, J. (2017). A governance study of corporate ownership in the insurance industry. Journal of Insurance Issues, 23-60.

575. Popadak, J. (2013). A corporate culture channel: How increased shareholder governance reduces firm value. Available at SSRN, 2345384.

576. Posner, E. A. (1996). Law, economics, and inefficient norms. University of Pennsylvania Law Review, 144(5), 1697-1744.

577. Posner, R. A. (1977). Gratuitous promises in economics and law. The Journal of Legal Studies, 6(2), 411-426.

578. Posner, R. A. (1979). Utilitarianism, economics, and legal theory. The Journal of Legal Studies, 8(1), 103-140.

579. Posner, R. A. (1979). Utilitarianism, economics, and legal theory. The Journal of Legal Studies, 8(1), 103-140.

580. Posner, R. A. (1987). The law and economics movement. The American Economic Review, 77(2), 1-13.

581. Posner, R. A. (2005). Intellectual property: The law and economics approach. Journal of Economic Perspectives, 19(2), 57-73.

582. Posner, R. A., \& Rosenfield, A. M. (1977). Impossibility and related doctrines in contract law: An economic analysis. The Journal of Legal Studies, 6(1), 83-118.

583. Prasad, B. C. (2003). Institutional economics and economic development. International Journal of Social Economics.

584. Preston, L. E., \& O'bannon, D. P. (1997). The corporate social-financial performance relationship: A typology and analysis. Business \& Society, 36(4), 419-429.

585. Puffer, S. M., \& McCarthy, D. J. (1997). Business ethics in a transforming economy: Applying the integrative social contracts theory to Russia. U. Pa. J. Int'l Econ. L., 18, 1281.

586. Pugliese, A., Minichilli, A., \& Zattoni, A. (2014). Integrating agency and resource dependence theory: Firm profitability, industry regulation, and board task performance. Journal of Business Research, 67(6), 1189-1200.

587. Qu, W., \& Leung, P. (2006). Cultural impact on Chinese corporate disclosure-a corporate governance perspective. Managerial Auditing Journal.

588. Quaglia, L. (2007). Committee governance in the financial sector in the European Union. Sussex European Institute Working Paper, (96), 1-36.

589. Quiggin, J. (2002). Economic governance and microeconomic reform. Economic governance and institutional dynamics, 158-177. 
590. Quinn, R. E., \& Rohrbaugh, J. (1981). A competing values approach to organizational effectiveness. Public productivity review, 122-140.

591. Randall, D. M., \& Gibson, A. M. (1990). Methodology in business ethics research: A review and critical assessment. Journal of business ethics, 9(6), 457-471.

592. Rao, D. T. (2000). Privatisation and foreign participation in (life) insurance sector. Economic and political Weekly, 1107-1120.

593. Rao, M. T., Brown, C. V., \& Perkins, W. C. (2007). Host country resource availability and information system control mechanisms in multinational corporations: an empirical test of resource dependence theory. Journal of Management Information Systems, 23(4), 11-28.

594. Rediker, K. J., \& Seth, A. (1995). Boards of directors and substitution effects of alternative governance mechanisms. Strategic management journal, 16(2), 85-99.

595. Reed, D. (2002). Corporate governance reforms in developing countries. Journal of business ethics, 37(3), 223-247.

596. Regan, T. (1980). Utilitarianism, vegetarianism, and animal rights. Philosophy \& Public Affairs, 305-324.

597. Rehan, F., Block, J. H., \& Fisch, C. (2019). Entrepreneurship in Islamic communities: How do Islamic values and Islamic practices influence entrepreneurship intentions? Journal of Enterprising Communities: People and Places in the Global Economy, Forthcoming.

598. Reidenbach, R. E., \& Robin, D. P. (1990). Toward the development of a multidimensional scale for improving evaluations of business ethics. Journal of business ethics, 9(8), 639-653.

599. Reisen, H. (2001, May). Will Basel II contribute to convergence in international capital flows?. In Austrian National Bank Conference, Vienna (Vol. 31).

600. Reisman, D. A. (2007). Economic sociology and institutional economics. Journal of Institutional Economics, 3(1), 91-112.

601. Reitenga, A. L., \& Tearney, M. G. (2003). Mandatory CEO retirements, discretionary accruals, and corporate governance mechanisms. Journal of Accounting, Auditing \& Finance, 18(2), 255-280.

602. Rezaee, Z. (2005). Causes, consequences, and deterence of financial statement fraud. Critical Perspectives on Accounting, 16(3), 277-298.

603. Riker, W. H., \& Sened, I. (1991). A political theory of the origin of property rights: Airport slots. American Journal of Political Science, 951-969.

604. Rivera, J. M., Muñoz, M. J., \& Moneva, J. M. (2017). Revisiting the relationship between corporate stakeholder commitment and social and financial performance. Sustainable Development, 25(6), 482-494.

605. Roberts, P. W., \& Greenwood, R. (1997). Integrating transaction cost and institutional theories: Toward a constrained-efficiency framework for understanding organizational design adoption. Academy of management review, 22(2), 346-373.

606. Robinson, F. (2011). Stop talking and listen: Discourse ethics and feminist care ethics in international political theory. Millennium, 39(3), 845-860.

607. Rochet, J. C. (2004). Macroeconomic shocks and banking supervision. Journal of Financial Stability, 1(1), 93-110.

608. Rochet, J. C. (2004). Market discipline in banking: Where do we stand. Market Discipline Across Countries and Industries, ed. C Borio, WC Hunter, G Kaufman, K Tsatsaronis, 6, 55-68.

609. Rockness, H., \& Rockness, J. (2005). Legislated ethics: From Enron to Sarbanes-Oxley, the impact on corporate America. Journal of Business Ethics, 57(1), 31-54.

610. Roe, M. J. (1996). Chaos and evolution in law and economics. Harvard Law Review, 109(3), 641-668.

611. Rose-Ackerman, S. (1985). Inalienability and the theory of property rights. Columbia Law Review, 85(5), 931-969.

612. Rose-Ackerman, S. (1988). Progressive Law and Economics. And the New Administrative Law. The Yale Law Journal, 98(2), 341-368. 
613. Ross, S. A. (1973). The economic theory of agency: The principal's problem. The American economic review, 63(2), 134-139.

614. Roth, K., \& O'donnell, S. (1996). Foreign subsidiary compensation strategy: An agency theory perspective. Academy of management Journal, 39(3), 678-703.

615. Rothenberg, S., Hull, C. E., \& Tang, Z. (2017). The impact of human resource management on corporate social performance strengths and concerns. Business \& Society, 56(3), 391-418.

616. Rowley, T. J. (1997). Moving beyond dyadic ties: A network theory of stakeholder influences. Academy of management Review, 22(4), 887-910.

617. Rowley, T., \& Berman, S. (2000). A brand new brand of corporate social performance. Business \& society, 39(4), 397-418.

618. Ruf, B. M., Muralidhar, K., Brown, R. M., Janney, J. J., \& Paul, K. (2001). An empirical investigation of the relationship between change in corporate social performance and financial performance: A stakeholder theory perspective. Journal of business ethics, 32(2), 143-156.

619. Ruggie, J. G. (1998). What makes the world hang together? Neo-utilitarianism and the social constructivist challenge. International organization, 52(4), 855-885.

620. Russo, A., \& Perrini, F. (2010). Investigating stakeholder theory and social capital: CSR in large firms and SMEs. Journal of Business ethics, 91(2), 207-221.

621. Rutherford, M. (2001). Institutional economics: then and now. Journal of economic perspectives, 15(3), 173-194.

622. Ryan, L. V., Buchholtz, A. K., \& Kolb, R. W. (2010). New directions in corporate governance and finance: Implications for business ethics research. Business Ethics Quarterly, 20(4), 673-694.

623. Saharso, S. (2003). Feminist ethics, autonomy and the politics of multiculturalism. Feminist Theory, 4(2), 199-215.

624. Salacuse, J. W. (2003). Corporate governance, culture and convergence: Corporations American style or with a European touch?. European Business Law Review, 14(5), 471-496.

625. Samuels, W. J. (1995). The present state of institutional economics. Cambridge Journal of Economics, 19(4), 569-590.

626. Samuelson, P. A. (1937). A note on measurement of utility. The review of economic studies, $4(2), 155-161$.

627. Sanchez, A. V., \& de la Merced, P. (2004). Development of corporate governance systems: Agency theory versus stewardship theory in welsh agrarian cooperative societies. University of Huelva and CENTRA, Head of the Management and Marketing Department.

628. Sanchis, A., Segovia, M. J., Gil, J. A., Heras, A., \& Vilar, J. L. (2007). Rough sets and the role of the monetary policy in financial stability (macroeconomic problem) and the prediction of insolvency in insurance sector (microeconomic problem). European Journal of Operational Research, 181(3), 1554-1573.

629. San-Jose, L., Retolaza, J. L., \& Gutierrez-Goiria, J. (2009). Ethical banks: an Alternative in the Financial Crisis. Available at SSRN 1416757.

630. San-Jose, L., Retolaza, J. L., \& Gutierrez-Goiria, J. (2011). Are ethical banks different? A comparative analysis using the radical affinity index. Journal of business ethics, 100(1), 151-173.

631. Santiso, C. (2006). Banking on Accountability? Strengthening budget oversight and public sector auditing in emerging economies. Public Budgeting \& Finance, 26(2), 66-100.

632. Sarı̈ül, H. (2012). Küçük ve orta büyüklükteki işletmelerde muhasebe ve finansal raporlama uygulamalarının Basel I-II-III kriterlerine uygunluğunun ölçülmesi: Bir araştırma (Doctoral dissertation, Selçuk Üniversitesi Sosyal Bilimler Enstitüsü).

633. Sarıŏlu, K. (2002 Ekim). "Enron Olayı”. Yönetim Dergisi.

634. Schaltegger, S., Hörisch, J., \& Freeman, R. E. (2019). Business cases for sustainability: a stakeholder theory perspective. Organization \& Environment, 32(3), 191-212.

635. Scherer, A. G., \& Patzer, M. (2011). Beyond universalism and relativism: Habermas's contribution to discourse ethics and its implications for intercultural ethics and organization theory. Research in the Sociology of Organizations, 32, 155-180. 
636. Schich, S. (2009). Challenges associated with the expansion of deposit insurance coverage during fall 2008. Economics: The Open-Access, Open-Assessment E-Journal, 3.

637. Schilirò, D. (2012). Bounded rationality and perfect rationality: Psychology into economics. Theoretical and Practical Research in Economic Fields (TPREF), 3(06), 99-108.

638. Schillemans, T. (2013). Moving beyond the clash of interests: On stewardship theory and the relationships between central government departments and public agencies. Public Management Review, 15(4), 541-562.

639. Scholl, H. J. (2001). Applying stakeholder theory to e-government. In Towards the E-society (pp. 735-747). Springer, Boston, MA.

640. Scholtens, B. (2009). Corporate social responsibility in the international banking industry. Journal of Business Ethics, 86(2), 159-175.

641. Schwartz, A., \& Scott, R. E. (2003). Contract theory and the limits of contract law. Yale LJ, 113, 541.

642. Schwartz, A., \& Watson, J. (2004). The law and economics of costly contracting. Journal of Law, Economics, and Organization, 20(1), 2-31.

643. Scott, A. J. (1986). Industrial organization and location: Division of labor, the firm, and spatial process. Economic geography, 62(3), 215-231.

644. Segal, L., \& Lehrer, M. (2012). The institutionalization of stewardship: Theory, propositions, and insights from change in the Edmonton public schools. Organization Studies, 33(2), 169-201.

645. Sen, A. (1979). Utilitarianism and welfarism. The Journal of Philosophy, 76(9), 463-489.

646. Sen, A. (2005). Why exactly is commitment important for rationality?. Economics \& Philosophy, 21(1), 5-14.

647. Seth, A., \& Thomas, H. (1994). Theories of the firm: Implications for strategy research. Journal of Management Studies, 31(2), 165-192.

648. Shah, S. (2006). Sexual division of labor in Adam Smith's work. Journal of the History of Economic Thought, 28(2), 221-241.

649. Shanahan, K. J., \& Hyman, M. R. (2003). The development of a virtue ethics scale. Journal of Business Ethics, 42(2), 197-208.

650. Shankman, N. A. (1999). Reframing the debate between agency and stakeholder theories of the firm. Journal of Business Ethics, 19(4), 319-334.

651. Shepherd, D. A., Wennberg, K., Suddaby, R., \& Wiklund, J. (2019). What are we explaining? A review and agenda on initiating, engaging, performing, and contextualizing entrepreneurship. Journal of Management, 45(1), 159-196.

652. Shi, W., Connelly, B. L., \& Hoskisson, R. E. (2017). External corporate governance and financial fraud: Cognitive evaluation theory insights on agency theory prescriptions. Strategic Management Journal, 38(6), 1268-1286.

653. Simon, H. A. (1978). Rationality as process and as product of thought. The American economic review, 68(2), 1-16.

654. Simon, H. A. (1986). Rationality in psychology and economics. Journal of Business, S209-S224.

655. Simon, H. A. (1993). Altruism and economics. The American Economic Review, 83(2), 156-161.

656. Sinani, E., Stafsudd, A., Thomsen, S., Edling, C., \& Randøy, T. (2008). Corporate governance in Scandinavia: Comparing networks and formal institutions. European Management Review, 5(1), 27-40.

657. Singer, M. G. (1977). Actual consequence utilitarianism. Mind, 86(341), 67-77.

658. Singer, P. (1980). Utilitarianism and vegetarianism. Philosophy \& Public Affairs, 325-337.

659. Singh, A. (2003). Competition, corporate governance and selection in emerging markets. The Economic Journal, 113(491), F443-F464.

660. Singh, P. J., Power, D., \& Chuong, S. C. (2011). A resource dependence theory perspective of ISO 9000 in managing organizational environment. Journal of Operations Management, 29(12), 49-64. 
661. Sironi, A., \& Zazzara, C. (2003). The Basel Committee proposals for a new capital accord: implications for Italian banks. Review of financial economics, 12(1), 99-126.

662. Smart, J. J. C. (1956). Extreme and restricted utilitarianism. The Philosophical Quarterly (1950), 6(25), 344-354.

663. Smith, I. (2003). The law and economics of marriage contracts. Journal of economic surveys, $17(2), 201-226$.

664. Sobel, J. H. (1976). Utilitarianism and past and future mistakes. Noûs, 195-219.

665. Sofianou, E. (1995). Post-modernism and the notion of rationality in economics. Cambridge Journal of Economics, 19, 373-373.

666. Solomon, R. C. (1992). Corporate roles, personal virtues: An Aristotelean approach to business ethics. Business Ethics Quarterly, 2(3), 317-339.

667. Spicer, A. (2009). The normalization of corrupt business practices: Implications for integrative social contracts theory (ISCT). Journal of Business Ethics, 88(4), 833-840.

668. Spicer, A., Dunfee, T. W., \& Bailey, W. J. (2004). Does national context matter in ethical decision making? An empirical test of integrative social contracts theory. Academy of management Journal, 47(4), 610-620.

669. Stansbury, J. (2009). Reasoned moral agreement: Applying discourse ethics within organizations. Business Ethics Quarterly, 19(1), 33-56.

670. Stanwick, P. A., \& Stanwick, S. D. (1998). The relationship between corporate social performance, and organizational size, financial performance, and environmental performance: An empirical examination. Journal of business ethics, 17(2), 195-204.

671. Starmer, C. (2000). Developments in non-expected utility theory: The hunt for a descriptive theory of choice under risk. Journal of economic literature, 38(2), 332-382.

672. Starmer, C. (2000). Developments in non-expected utility theory: The hunt for a descriptive theory of choice under risk. Journal of economic literature, 38(2), 332-382.

673. Steffen, T. (2008). Solvency II and the Work of CEIOPS. The Geneva Papers on Risk and Insurance-Issues and Practice, 33(1), 60-65.

674. Sternberg, E. (1997). The defects of stakeholder theory. Corporate Governance: An International Review, 5(1), 3-10.

675. Steurer, R. (2006). Mapping stakeholder theory anew: from the 'stakeholder theory of the firm'to three perspectives on business-society relations. Business strategy and the environment, 15(1), 55-69.

676. Steurer, R., Langer, M. E., Konrad, A., \& Martinuzzi, A. (2005). Corporations, stakeholders and sustainable development I: a theoretical exploration of business-society relations. Journal of business ethics, 61(3), 263-281.

677. Stigler, G. J. (1950). The development of utility theory. I. Journal of political economy, 58(4), 307-327.

678. Stigler, G. J. (1972). The law and economics of public policy: A plea to the scholars. The Journal of Legal Studies, 1(1), 1-12.

679. Stigler, G. J. (1992). Law or economics?. The Journal of Law and Economics, 35(2), 455-468.

680. Stiglitz, J. E. (1982). Utilitarianism and horizontal equity: The case for random taxation.

681. Stroh, L. K., Brett, J. M., Baumann, J. P., \& Reilly, A. H. (1996). Agency theory and variable pay compensation strategies. Academy of Management Journal, 39(3), 751-767.

682. Sturm, T., \& Oh, E. (2010). Natural disasters as the end of the insurance industry? Scalar competitive strategies, alternative risk transfers, and the economic crisis. Geoforum, 41(1), 154-163.

683. Su, F., Mao, J. Y., \& Jarvenpaa, S. L. (2014). How do IT outsourcing vendors respond to shocks in client demand? A resource dependence perspective. Journal of Information Technology, 29(3), 253-267.

684. Süer, A. Z. (2006). Profesyonel Muhasebe Mesleğinde Enron Skandali ve Sonrasi Gelişmeler. Retrieved June, 4, 2017.

685. Swanson, C. E. (1999). The division of labor and the extent of the market. Economics Letters, 62(1), 135-138. 
686. Swanson, D. L. (1995). Addressing a theoretical problem by reorienting the corporate social performance model. Academy of management review, 20(1), 43-64.

687. Swanson, D. L. (1999). Toward an integrative theory of business and society: A research strategy for corporate social performance. Academy of management review, 24(3), 506-521.

688. Tadesse, S. (2006). The economic value of regulated disclosure: Evidence from the banking sector. Journal of Accounting and Public Policy, 25(1), 32-70.

689. Takala, T. (1998). Postmodern Business Ethics-Is It Possible, Is It Relevant?.

690. Tammone, W. (1995). Competition, the division of labor, and Darwin's principle of divergence. Journal of the History of Biology, 109-131.

691. Tanaka, M. (2002). How do bank capital and capital adequacy regulation affect the monetary transmission mechanism?.

692. Taylor, M. M., Quintyn, M. M., \& Hüpkes, M. E. H. (2005). The Accountability of Financial Sector Supervisors: Principles and Practice (No. 5-51). International Monetary Fund.

693. Teece, D. J. (1986). Transactions cost economics and the multinational enterprise An Assessment. Journal of Economic Behavior \& Organization, 7(1), 21-45.

694. Ten Bos, R. (1997). Essai: Business ethics and Bauman ethics. Organization Studies, 18(6), 997-1014.

695. Thompson, J. A., \& Hart, D. W. (2006). Psychological contracts: A nano-level perspective on social contract theory. Journal of Business Ethics, 68(3), 229-241.

696. Tian, G. (2000). Property rights and the nature of Chinese collective enterprises. Journal of comparative Economics, 28(2), 247-268.

697. Tisdell, C. A. (1975). Concepts of rationality in economics. Inst..

698. Tosi Jr, H. L., \& Gomez-Mejia, L. R. (1989). The decoupling of CEO pay and performance: An agency theory perspective. Administrative Science Quarterly, 169-189.

699. Tosi, H. L., Brownlee, A. L., Silva, P., \& Katz, J. P. (2003). An empirical exploration of decision冈making under agency controls and stewardship structure. Journal of Management Studies, 40(8), 2053-2071.

700. Tower, I., \& Impavido, G. (2009). How the financial crisis affects pensions and insurance and why the impacts matter (No. 9-151). International Monetary Fund.

701. Tremblay, M., Cote, J., \& Balkin, D. B. (2003). Explaining sales pay strategy using agency, transaction cost and resource dependence theories. Journal of Management Studies, 40(7), 1651-1682.

702. Trevino, L. K. (1992). Moral reasoning and business ethics: Implications for research, education, and management. Journal of Business Ethics, 11(5-6), 445-459.

703. Trevino, L. K., \& Brown, M. E. (2004). Managing to be ethical: Debunking five business ethics myths. Academy of Management Perspectives, 18(2), 69-81.

704. Trevino, L. K., \& Weaver, G. R. (1994). Business ETHICS/BUSINESS ethics: One field or two?. Business Ethics Quarterly, 113-128.

705. Treviño, L. K., \& Weaver, G. R. (1999). The stakeholder research tradition: Converging theorists-not convergent theory. Academy of Management Review, 24(2), 222-227.

706. Trichet, J. C. (2005). Financial stability and the insurance sector. The Geneva Papers on risk and insurance-issues and practice, 30(1), 65-71.

707. Tsalikis, J., \& Fritzsche, D. J. (2013). Business ethics: A literature review with a focus on marketing ethics. In Citation Classics from the Journal of Business Ethics (pp. 337-404). Springer, Dordrecht.

708. Tsang, E. W. (2006). Behavioral assumptions and theory development: The case of transaction cost economics. Strategic Management Journal, 27(11), 999-1011.

709. Tuan, L. T. (2011). Organisational culture and trust as organisational factors for corporate governance. International Journal of Management and Enterprise Development, 11(2-4), $142-162$.

710. Turban, D. B., \& Greening, D. W. (1997). Corporate social performance and organizational attractiveness to prospective employees. Academy of management journal, 40(3), 658-672. 
711. Turvey, R. (1969). Marginal cost. The Economic Journal, 79(314), 282-299.

712. Tversky, A. (1975). A critique of expected utility theory: Descriptive and normative considerations. Erkenntnis, 163-173.4

713. Ullmann, A. A. (1985). Data in search of a theory: A critical examination of the relationships among social performance, social disclosure, and economic performance of US firms. Academy of management review, 10(3), 540-557.,

714. Ulrich, D., \& Barney, J. B. (1984). Perspectives in organizations: resource dependence, efficiency, and population. Academy of Management Review, 9(3), 471-481.

715. Üçgün, S. (2010). Basel II kriterleri kapsamında operasyonel risk. Beta Basım Yayım.

716. Vadlamannati, K. C. (2008). Do insurance sector growth and reforms affect economic development? Empirical evidence from India. Margin: The Journal of Applied Economic Research, 2(1), 43-86.

717. Valentine, S., \& Godkin, L. (2017). Banking employees' perceptions of corporate social responsibility, value-fit commitment, and turnover intentions: Ethics as social glue and attachment. Employee Responsibilities and Rights Journal, 29(2), 51-71.

718. Vallejo, M. C. (2009). The effects of commitment of non-family employees of family firms from the perspective of stewardship theory. Journal of business ethics, 87(3), 379-390.

719. Vallentyne, P. (1993). Utilitarianism and infinite utility.

720. Van Buren, H. J. (2000). The bindingness of social and psychological contracts: Toward a theory of social responsibility in downsizing. Journal of Business Ethics, 25(3), 205-219.

721. Van Roy, P. (2005). Credit ratings and the standardised approach to credit risk in Basel II.

722. Van Staveren, I. (2007). Beyond utilitarianism and deontology: Ethics in economics. Review of Political Economy, 19(1), 21-35.

723. Vanberg, V. J. (2006). Rationality, rule-following and emotions: On the economics of moral preferences (No. 0621). Papers on economics and evolution.

724. Vatn, A. (2005). Rationality, institutions and environmental policy. Ecological Economics, 55(2), 203-217.

725. Vaughn, M., \& Ryan, L. V. (2006). Corporate governance in South Africa: a bellwether for the continent?. Corporate Governance: An International Review, 14(5), 504-512.

726. Veblen, T. (1898). Why is economics not an evolutionary science?. The quarterly journal of economics, 12(4), 373-397.

727. Veblen, T. (1909). The limitations of marginal utility. Journal of political Economy, 17(9), 620-636.

728. Velthuis, B. O. (1999). The Changing Relationship Between Economic Sociology and Institutional Economics: From Talcott Parsons to Mark Granovetter1. American journal of economics and sociology, 58(4), 629-649.

729. Verbeke, A., \& Kano, L. (2012). The transaction cost economics theory of the family firm: Family-based human asset specificity and the bifurcation bias. Entrepreneurship Theory and Practice, 36(6), 1183-1205.

730. Vickrey, W. (1945). Measuring marginal utility by reactions to risk. Econometrica: Journal of the Econometric Society, 319-333.

731. Vishwanath, T., \& Kaufmann, D. (2001). Toward transparency: New approaches and their application to financial markets. The World Bank Research Observer, 16(1), 41-57.

732. Viswesvaran, C., \& Deshpande, S. P. (1996). Ethics, success, and job satisfaction: A test of dissonance theory in India. Journal of Business Ethics, 15(10), 1065-1069.

733. Wade, M., \& Hulland, J. (2004). The resource-based view and information systems research: Review, extension, and suggestions for future research. MIS quarterly, 28(1), 107-142.

734. Wahab, E. A. A., Pitchay, A. A., \& Ali, R. (2015). Culture, corporate governance and analysts forecast in Malaysia. Asian Review of Accounting.

735. Wallenius, J., Dyer, J. S., Fishburn, P. C., Steuer, R. E., Zionts, S., \& Deb, K. (2008). Multiple criteria decision making, multiattribute utility theory: Recent accomplishments and what lies ahead. Management science, 54(7), 1336-1349. 
736. Wang, J. L., Jeng, V., \& Peng, J. L. (2007). The impact of corporate governance structure on the efficiency performance of insurance companies in Taiwan. The Geneva Papers on Risk and Insurance-Issues and Practice, 32(2), 264-282.

737. Ward, J. L. (1997). Growing the family business: Special challenges and best practices. Family business review, 10(4), 323-337.

738. Wartick, S. L., \& Cochran, P. L. (1985). The evolution of the corporate social performance model. Academy of management review, 10(4), 758-769.

739. Weaver, G. R., \& Trevino, L. K. (1994). Normative and empirical business ethics: Separation, marriage of convenience, or marriage of necessity?. Business Ethics Quarterly, 129-143.

740. Weber, J. A. (2007). Business ethics training: Insights from learning theory. Journal of Business Ethics, 70(1), 61-85.

741. Weinrib, E. J. (1980). Utilitarianism, Economics, and Legal Theory. U. Toronto LJ, 30, 307.

742. Weiss, M. A. (2010). Systemic risk and the US insurance sector. Center for Insurance Policy \& Research, National Association of Insurance Commissioners. http://www. naic. org/documents/cipr_weiss_systemic_risk_100223.pdf.

743. Wempe, B. (2005). In defense of a self-disciplined, domain-specific social contract theory of business ethics. Business Ethics Quarterly, 15(1), 113-135.

744. Wernerfelt, B. (1984). A resource区based view of the firm. Strategic management journal, 5(2), 171-180.

745. West, A. (1999). The flute factory: an empirical measurement of the effect of the division of labor on productivity and production cost. The American Economist, 43(1), 82-87.

746. Whetstone, J. T. (2001). How virtue fits within business ethics. Journal of Business Ethics, 33(2), 101-114.

747. Whitaker, A. C. (1916). Fetter's Principles of Economics. Political Science Quarterly, 31(3), 430-444.

748. Williamson, O. (2000). Contract and economic organization. Revue d'economie industrielle, 92(1), 55-66.

749. Williamson, O. E. (1979). Transaction-cost economics: the governance of contractual relations. The journal of Law and Economics, 22(2), 233-261.

750. Williamson, O. E. (1981). The economics of organization: The transaction cost approach. American journal of sociology, 87(3), 548-577.

751. Williamson, O. E. (1998). Transaction cost economics: how it works; where it is headed. De economist, 146(1), 23-58.

752. Williamson, O. E. (1999). Public and private bureaucracies: a transaction cost economics perspectives. The Journal of Law, Economics, and Organization, 15(1), 306-342.

753. Williamson, O. E. (2000). The new institutional economics: taking stock, looking ahead. Journal of economic literature, 38(3), 595-613.

754. Williamson, O. E. (2002). The theory of the firm as governance structure: from choice to contract. Journal of economic perspectives, 16(3), 171-195.

755. Williamson, O. E. (2005). The economics of governance. American Economic Review, 95(2), $1-18$.

756. Williamson, O. E. (2008). Outsourcing: Transaction cost economics and supply chain management. Journal of supply chain management, 44(2), 5-16.

757. Williamson, O. E. (2010). Transaction cost economics: The natural progression. American Economic Review, 100(3), 673-90.

758. Wintoki, M. B. (2007). Corporate boards and regulation: The effect of the Sarbanes-Oxley Act and the exchange listing requirements on firm value. Journal of Corporate Finance, 13(2-3), 229-250.

759. Wintoki, M. B., Linck, J. S., \& Netter, J. M. (2012). Endogeneity and the dynamics of internal corporate governance. Journal of Financial Economics, 105(3), 581-606.

760. Wood, D. J. (1991). Corporate social performance revisited. Academy of management review, 16(4), 691-718. 
761. Wood, D. J. (1991). Social issues in management: Theory and research in corporate social performance. Journal of Management, 17(2), 383-406.

762. Wood, D. J., \& Jones, R. E. (1995). Stakeholder mismatching: A theoretical problem in empirical research on corporate social performance. The International Journal of Organizational Analysis.

763. Wu, M. W., \& Shen, C. H. (2013). Corporate social responsibility in the banking industry: Motives and financial performance. Journal of Banking \& Finance, 37(9), 3529-3547.

764. Yasuda, H. (2005). Formation of strategic alliances in high-technology industries: comparative study of the resource-based theory and the transaction-cost theory. Technovation, 25(7), 763-770.

765. Yetim, F. (2011). Bringing discourse ethics to value sensitive design: pathways toward a deliberative future. AIS Transactions on Human-Computer Interaction, 3(2), 133-155.

766. Yoshikawa, T., Tsui-Auch, L. S., \& McGuire, J. (2007). Corporate governance reform as institutional innovation: The case of Japan. Organization science, 18(6), 973-988.

767. Young, K. L. (2012). Transnational regulatory capture? An empirical examination of the transnational lobbying of the Basel Committee on Banking Supervision. Review of International Political Economy, 19(4), 663-688.

768. Yusuf, D. İ. N. Ç., \& Cengiz, S. (2014). Muhasebe Denetiminde Hata ve Hilenin Denetçi Etiği Açısından İncelenmesi: Enron Skandalı Örneği. Çankırı Karatekin Üniversitesi Sosyal Bilimler Enstitüsü Dergisi, 5(1), 221-236.

769. Zahra, S. A., Hayton, J. C., Neubaum, D. O., Dibrell, C., \& Craig, J. (2008). Culture of family commitment and strategic flexibility: The moderating effect of stewardship. Entrepreneurship theory and practice, 32(6), 1035-1054.

770. Zakhem, A. (2008). Stakeholder management capability: A discourse-theoretical approach. Journal of business ethics, 79(4), 395-405.

771. Zhang, I. X. (2007). Economic consequences of the Sarbanes-Oxley Act of 2002. Journal of accounting and economics, 44(1-2), 74-115.

772. Zhang, X., Yang, J., \& Thomas, R. (2017). Mechanization outsourcing clusters and division of labor in Chinese agriculture. China Economic Review, 43, 184-195.

773. Zhang, Y., Zhou, J., \& Zhou, N. (2007). Audit committee quality, auditor independence, and internal control weaknesses. Journal of accounting and public policy, 26(3), 300-327.

774. Zsidisin, G. A., \& Ellram, L. M. (2003). An agency theory investigation of supply risk m anagement. Journal of supply chain management, 39(2), 15-27. 